Review

\title{
Current Advancements in Addressing Key Challenges of Therapeutic Antibody Design, Manufacture, and Formulation
}

\author{
Vicki Sifniotis $@$, Esteban Cruz, Barbaros Eroglu and Veysel Kayser *(1) \\ School of Pharmacy, Faculty of Medicine and Health, The University of Sydney, Sydney 2006, Australia; \\ vsif0221@uni.sydney.edu.au (V.S.); ecru7298@uni.sydney.edu.au (E.C.); barbaros.eroglu@sydney.edu.au (B.E.) \\ * Correspondence: veysel.kayser@sydney.edu.au; Tel.: +61-2-9351-3391
}

Received: 16 April 2019; Accepted: 31 May 2019; Published: 3 June 2019

check for updates

\begin{abstract}
Therapeutic antibody technology heavily dominates the biologics market and continues to present as a significant industrial interest in developing novel and improved antibody treatment strategies. Many noteworthy advancements in the last decades have propelled the success of antibody development; however, there are still opportunities for improvement. In considering such interest to develop antibody therapies, this review summarizes the array of challenges and considerations faced in the design, manufacture, and formulation of therapeutic antibodies, such as stability, bioavailability and immunological engagement. We discuss the advancement of technologies that address these challenges, highlighting key antibody engineered formats that have been adapted. Furthermore, we examine the implication of novel formulation technologies such as nanocarrier delivery systems for the potential to formulate for pulmonary delivery. Finally, we comprehensively discuss developments in computational approaches for the strategic design of antibodies with modulated functions.
\end{abstract}

Keywords: therapeutic antibody; stability; aggregation; manufacture challenges; formulation

\section{Introduction}

Since the first therapeutic monoclonal antibody $(\mathrm{mAb})$ Orthoclone OKT3 ${ }^{\circledR}$ (Janssen Biotech, Horsham, PA, USA) was approved by the USA Food and Drug Administration in 1986, whole antibody therapeutics have become and persistently remain the most dominant and significant biologic therapeutic platform in the pharmaceutical industry [1,2]. To date, therapeutic antibodies treat a plethora of indications including cancers, infections, autoimmune disorders, and cardiovascular and neurological diseases [3]. The whole antibody therapeutics platform is regarded as the most promising class of pharmaceutical technology to date; it is continually being applied to newly identified biological targets and implemented in many formats to produce strategically engineered next generation antibody therapeutics, otherwise termed "biobetters" [4-9]. The international ImMunoGeneTics information system ${ }^{\circledR}$ (IMGT ${ }^{\circledR}$, Montpellier, France) database reveals that as of December 2018, 65 whole antibodies and 18 next generation fragment or recombinant fusion antibody-based therapies are approved for clinical use, with hundreds more in clinical trials expected to reach market. 


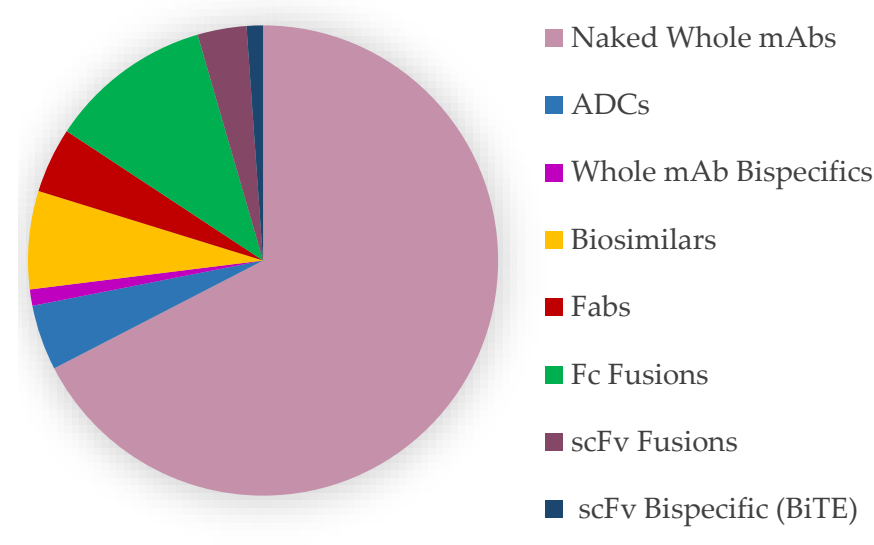

(a)

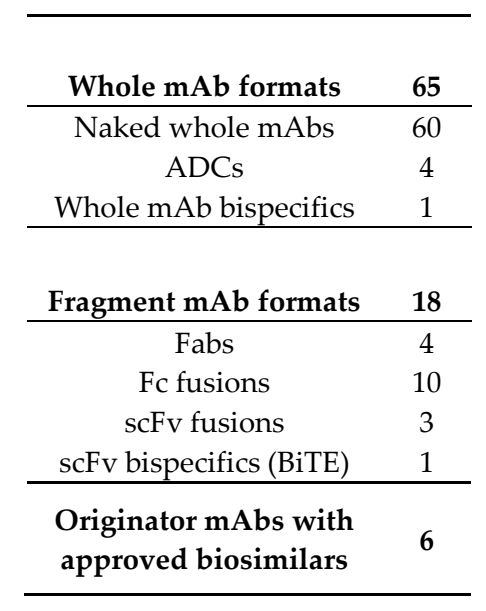

(b)

Figure 1. The proportions of therapeutic antibody formats approved for therapeutic use as of December 2018, IMGT $^{\circledR}$ depicted through (a) a pie chart and (b) a table format.

Whole therapeutic mAbs are presently the dominant antibody platform approved for clinical use (Figure 1), although antibody engineering technologies have advanced in recent years to produce highly optimized, strategically engineered biobetter therapies, along with biosimilar mAbs reaching market to compete against their originator. Further whole $\mathrm{mAb}$ formats include antibody-drug conjugates (ADCs), bispecifics, isotype-switched, and glycoengineered. These additional formats have been strategically designed to introduce exceptional potency, to engage dual biological targets, and to modulate $\mathrm{Fc}_{\mathrm{c}}$ effector functions. Fragments of mAbs such as the crystallizable fragment $\left(\mathrm{Fc}_{\mathrm{c}}\right)$, antigen binding fragment $(\mathrm{Fab})$, and single-chain variable fragment ( $\mathrm{scFv})$ possess key functions such as specificity to a biological target or immunological activation. The isolation of these fragments for fusion with other $\mathrm{mAb}$ fragments, biologically functional proteins, cytotoxic drugs, or drug carriers has been the crux of ingenuity in developing the next generation of biobetter therapies [4-15]. Figure 2 depicts several examples of prominent biobetter formats, providing a general representation of current fragment $\mathrm{mAbs}$, whole $\mathrm{mAb}$ bispecifics, fragment $\mathrm{mAb}$ multispecifics, and fragment $\mathrm{mAb}$ fusion therapeutics. 

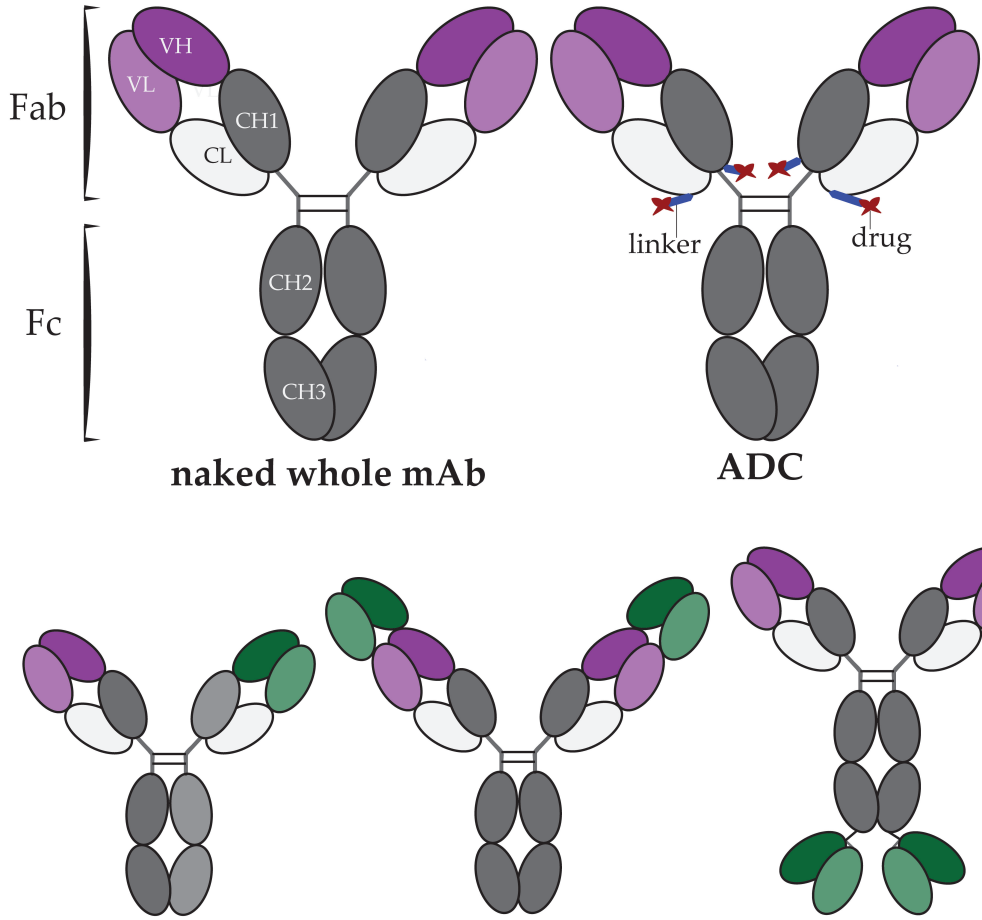

Triomab

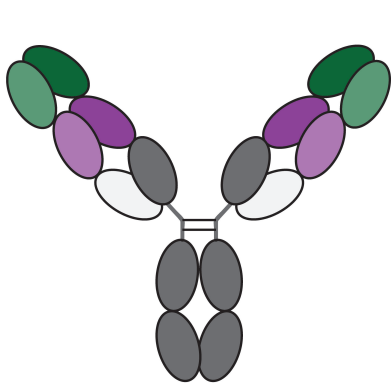

DVD-Ig

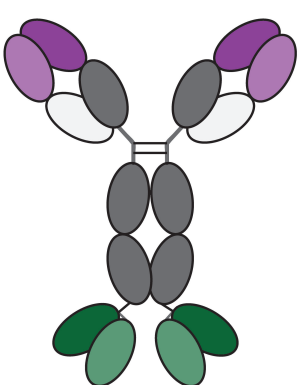

$\mathrm{IgG}-\mathrm{scFv}$

several whole $\mathrm{mAb}$ bispecific formats

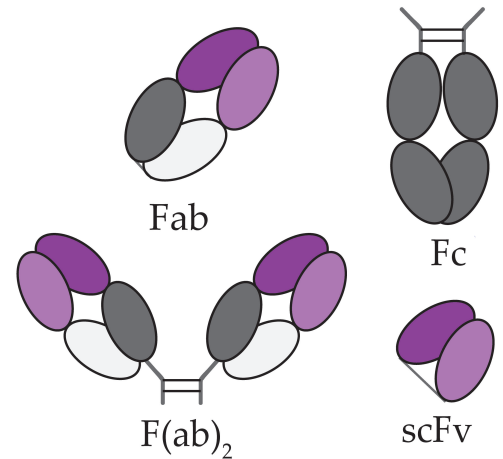

fragment $\mathrm{mAb}$ formats

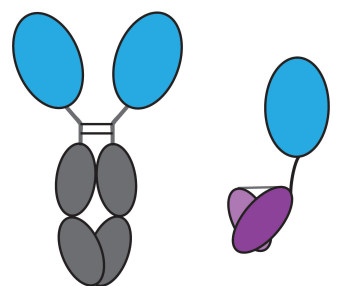

Fc and $\mathrm{scFv}$ fusion format (general)

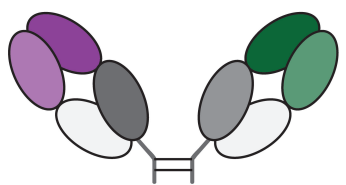

$\mathrm{F}(\mathrm{ab})_{2}$ bispecific

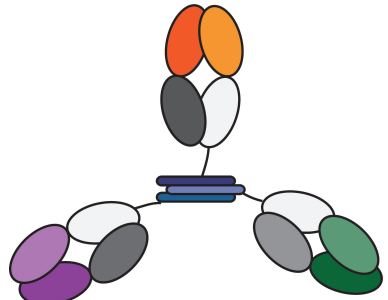

$\mathrm{F}(\mathrm{ab})_{3}$ trispecific

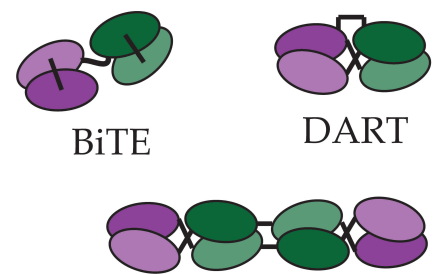

tand $\mathrm{Ab}$

several Fab and scFv multispecfic formats

Figure 2. Schematic representation of a whole monoclonal antibody (mAb), a fragment mAb, and prominent fusion $\mathrm{mAb}$ formats that have been developed for strategic therapeutic uses. Proteins fused to $\mathrm{mAb}$ fragments are depicted as blue ovals for a general representation; however, fusion proteins may vary in size and structure. Fragment formats include the crystallizable ( $\mathrm{Fc})$, antigen binding ( $\mathrm{Fab}$ and $\mathrm{F}(\mathrm{ab}) 2)$, and single-chain variable ( $\mathrm{scFv}$ ) fragments. Further whole mAb formats include the antibody-drug conjugate (ADC), triomab, dual variable domain immunoglobulin (DVD-Ig), and immunoglobulin-scFv fusion (IgG-scFv). Multispecific fragment formats include the $\mathrm{F}(\mathrm{ab}) 2$ bispecific, bispecific T-cell engager (BiTE), dual affinity re-targeting molecule (DART), and tandem diabody (tand $\mathrm{Ab})$.

\section{Overview of $\mathrm{mAb}$ Production Challenges and Considerations}

Whole therapeutic mAbs require a mammalian expression system to produce the biologically functional product; however, a mAb fragment and recombinant fusion $\mathrm{mAb}$ products with simplified (or lacking) glycosylation are suitable for lower organism expression platforms [16]. Unlike oligopeptides, which can be chemically synthesized, whole therapeutic mAbs are considerably larger (with monomer ranging from 140-160 kDa) and comprise of four peptide chains (two heavy and two light chains) bound together by disulfide bonds and interchain non-covalent interactions. Further to this, antibodies contain glycosylation in a conserved region of the Fc (N297) that contributes 
to its stability and immune effector functions $[17,18]$. Aside from peptide synthesis, cell machinery is required to glycosylate, fold, orient, and covalently bind the antibody peptide chains in order to produce the complete, biologically functional antibody product. Manufacturing biologically functional whole $\mathrm{mAb}$ product is therefore commercially unfeasible through chemical synthesis and insufficient in lower organism expression platforms such as bacteria, yeast, insect, and plant cells that may not have the machinery to produce the equivalent tertiary structure and glycosylation profiles. In particular, many industrially relevant bacterial strains such as E. coli are completely deficient in the machinery to add post-translational glycosylations; yeasts hyper-mannosylate glycans, which cause immunogenicity; and insect cells which are deficient in sialylation machinery and produce immunogenic glycan structures [16]. A secretion of the mAb product for purification is suboptimal for several lower organism expression platforms such as E. coli due to poor productivity and harsh culture conditions that promote product degradation. Protein is therefore produced intracellularly, as inclusion bodies and harvest involves further processing steps such as cell lysis, inclusion body recovery, protein solubilization, and renaturation prior to further downstream purification steps $[19,20]$. Despite these pitfalls, the development of lower organism expression systems is of high commercial interest due to the simplified culture conditions, cheaper media requirements, rapid organism growth, and higher product yield as compared to mammalian expression systems $[16,21]$.

In considering the requirements through the entire process of mAb discovery, manufacture, formulation, and disease treatment, several key challenges arise which have sparked overwhelming interest in pursuit of achieving better $\mathrm{mAb}$ manufacturing outcomes and treatment strategies. As with all biotherapeutics, mAbs and mAb-based therapeutics are limited to production in cell-based expression systems, which is considerably costly and inefficient, can have varied yields depending on the product and expression system, and requires downstream processing to remove biological contaminants introduced from the expression system. Despite affinity chromatography being a robust technology for the initial capture of a mAb for purification, the capture process and further downstream processes such as viral inactivation applies the $\mathrm{mAb}$ product to harsh $\mathrm{pH}$ and salt conditions, which can chemically degrade the $\mathrm{mAb}$, leading to product instability and loss $[5,22,23]$.

Many factors through the manufacture process influence glycosylation and charge heterogeneity of mAbs, which affects their biophysical and pharmacological properties. Though not specifically discussed in this review, the improvement and control $\mathrm{mAb}$ production technologies address these variations to reduce formulation heterogeneity and off-target cytotoxicities.

A common challenge, as seen with all biotherapeutics, is that $\mathrm{mAbs}$ and $\mathrm{mAb}$-based therapeutics are currently restricted to lyophilised and liquid-based formulations for intravenous (IV) or subcutaneous (SC) delivery to achieve maximum bioavailability. Protein self-association and intrinsic stability drive this limitation, in that viscosity and propensity to aggregate are dependent on $\mathrm{mAb}$ concentration. Formulations are optimized to achieve the highest dosing concentration at the minimum achievable volume for injection, without compromising the quality of the mAb in formulation [24]. Viscosity remains a key limiting factor for formulating as a SC administration-certain $\mathrm{mAb}$ therapies are suitable and others not based on their solubility, self-association, and aggregation profiles. Alternative non-invasive administration strategies such as pulmonary delivery causes additional mechanical stress that further contribute to mAb instability and loss. Furthermore, oral delivery is unsuitable due to chemical and enzymatic degradation, as well as poor absorption in the gastric and intestinal environments [5,25-29].

A brief overview of considerations through the different concept stages of therapeutic mAb development is depicted in Figure 3. The main challenges and considerations in the manufacture and formulation of $\mathrm{mAb}$ therapeutics are briefly summarized in Table 1. 


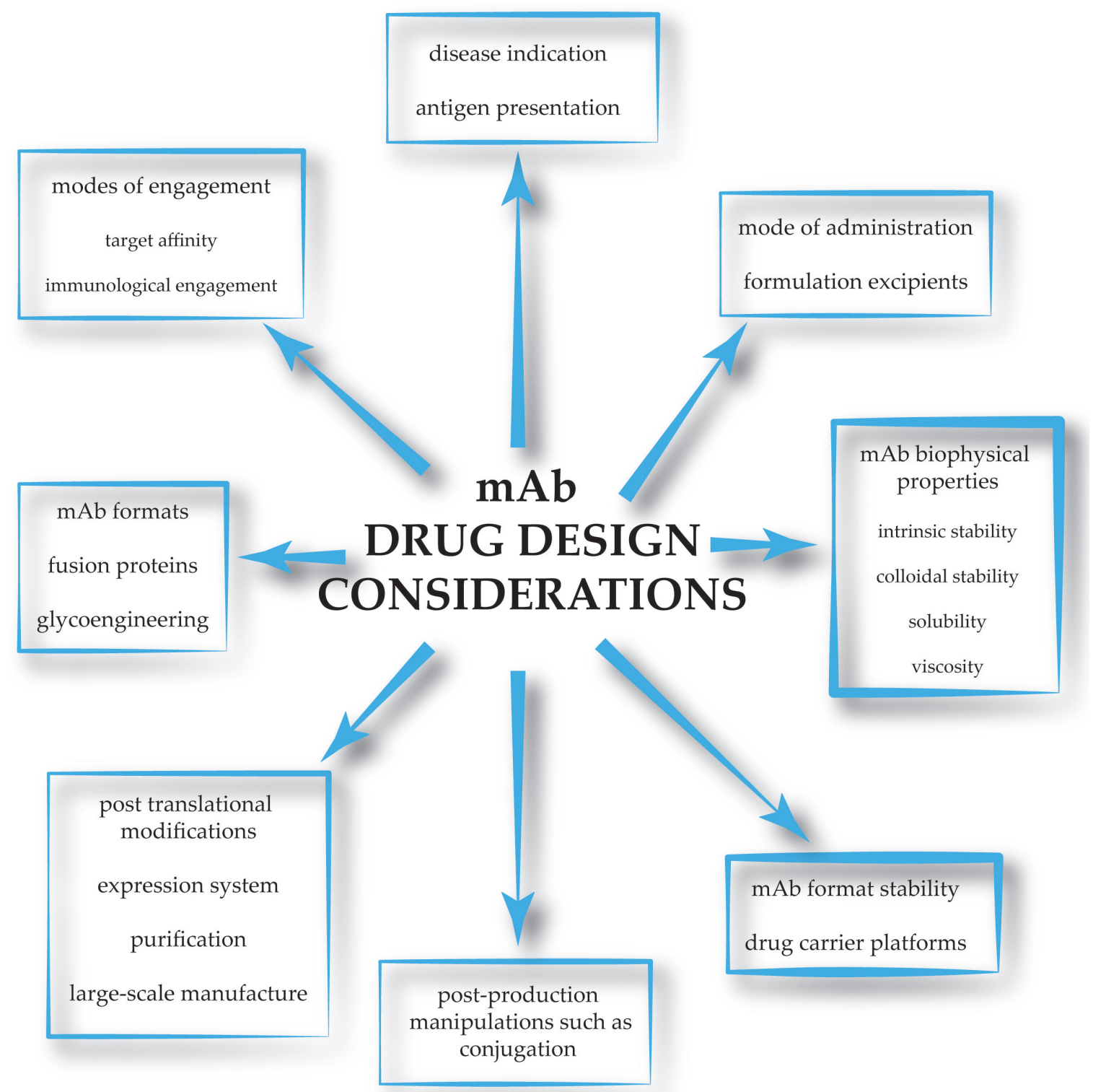

Figure 3. Schematic representation of the concept stages of mAb drug development in which considerations follow on from one process to the next in the design and manufacture of mAb-based therapeutics. 
Table 1. Summary of key technological advancements that address challenges and considerations in mAb design, manufacture, and formulation strategies.

\begin{tabular}{|c|c|}
\hline Challenges & Advancements \\
\hline \multicolumn{2}{|c|}{ Manufacture Considerations } \\
\hline Hybridoma technology produces immunogenic mAbs & Humanization technologies [4-6] \\
\hline Yield from hybridoma technology is variable & \multirow{2}{*}{$\begin{array}{l}\text { Commercial cell line development and recombinant technology [4-6]; lower } \\
\text { organism systems for fragment mAbs, mammalian systems for whole mAbs, and Fc } \\
\text { fusions }[16,30,31]\end{array}$} \\
\hline $\begin{array}{l}\text { Significance of post-translational modifications and higher-order structure in } \\
\text { mAb product }\end{array}$ & \\
\hline $\mathrm{CHO}$ expressed mAbs contain an immunogenic glycosylation profile & Human-based expression systems [16,30-32] \\
\hline HEK 293 expressed mAbs are prone to aggregation & HKB-11 and PER.C6 cell lines [32] \\
\hline Undesirable byproducts produced in the manufacture process & in vitro cell-free synthesis technology $[33,34]$ \\
\hline $\begin{array}{l}\text { Stability of } \mathrm{mAb} \text { affects manufacture yield due to product loss through aggregation in } \\
\text { downstream processing steps }\end{array}$ & $\begin{array}{l}\text { Enhancing mAb stability through framework mutations and hyperglycosylation } \\
{[5,35-40]}\end{array}$ \\
\hline \multicolumn{2}{|c|}{ Treatment Considerations for Drug Design and Formulation } \\
\hline $\begin{array}{l}\text { Susceptibility of mAb to degradation limits delivery to intravenous and } \\
\text { subcutaneous only }\end{array}$ & \multirow{2}{*}{$\begin{array}{l}\text { Enhancing mAb stability through framework mutations, hyperglycosylation } \\
{[5,35-40] \text {, and nanocarrier technologies }[8,41]}\end{array}$} \\
\hline Stability of mAb limits concentration of formulation & \\
\hline $\begin{array}{l}\text { Concentration of mAb affects viscosity and injection pressure for } \\
\text { subcutaneous delivery }\end{array}$ & Excipients, fragment mAbs, PEGylation, and hyperglycosylation $[25-27,41]$ \\
\hline Poor tissue penetration and biodistribution & Fragment mAbs and nanocarrier technologies [8,41,42]; high affinity ADCs [43-45] \\
\hline Reduced half-life in low MW species & $\begin{array}{l}\text { PEGylation, hyper-glycosylation and Fc fusion proteins }[8,41,46] \text {; modulation of FcRn } \\
\text { recycling through Fc mutation }[11,13]\end{array}$ \\
\hline Modulation of immunological engagement & Isotype switching, glycoengineering, and Fc mutations $[11,13,15,43,46]$ \\
\hline
\end{tabular}




\section{3. mAb Discovery and Manufacture Technologies}

Traditional technology for whole therapeutic antibody discovery required the immunization of animals-primarily mice with a target antigen for the generation of a mixed population of B-lymphocytes-producing antibody against the target. The B-lymphocytes would be isolated for immortalization to produce monoclonal hybridoma cell lines that secrete antibody candidates of interest for further panning through display technologies to isolate potential leads [5]. This method has led to the generation of highly specific $\mathrm{mAb}$ libraries of non-human origin that were potentially immunogenic and less efficacious at eliciting an immune response as compared to wholly human mAbs. Technologies arose to address immunogenicity by producing chimeric and humanized antibodies through the grafting of the variable domains (chimeric) or complementarity-determining region (CDR) residues (humanized) isolated from lead non-human antibodies to a human antibody framework. To further improve the humanization strategy, transgenic mice were developed with their murine antibody heavy and light chain genes replaced with equivalent human genes; they consequently expressed wholly human antibodies for discovery [4-6].

Phage display technology remains the most prominent selection technology for panning antibody gene pools for specificity to a target antigen, as it effectively couples the expression of $\mathrm{mAb}$ proteins to the genes that encode them for the panning of high affinity leads. Antibody variable genes from B-lymphocyte pools are isolated through polymerase chain reaction (PCR), and cloned into a phage expression vector that presents the expressed $\mathrm{mAb}$ on the surface of the phage, the library of vectors is rescued in phage, and the phage library is screened against a specific target antigen. Phage pools undergo several rounds of selection to isolate high affinity candidates, the variable genes of the lead $\mathrm{mAb}$ candidates can then be isolated and sequenced for the design of a mAb drug format and the development of a suitable expression platform [5,47]. Error-prone PCR-based mutagenesis has propelled display technology for the generation of enormous libraries for target affinity screening. Yeast surface display further improves these screening technologies, as glycosylation sites introduced in CDRs are expressed through this platform $[5,48]$.

The expression, yield, and quality of a mAb can vary quite substantially in hybridoma cell lines. High yielding mammalian expression systems have been developed to meet the commercial need for high expression efficiency, scalability, quality, and reproducibility. Antibody genes of interest are introduced into suitable expression vectors and transfected into highly efficient mammalian cell lines for antibody expression and secretion; a mAb can then be directly captured from the culture supernatant through affinity chromatography. Currently, the majority of mammalian expression systems for commercial whole therapeutic antibody expression are based on stable chinese hamster ovary ( $\mathrm{CHO})$, mouse myeloma (NS0), and mouse hybridoma (Sp2/0) cell lines [4,5]. However, in the context of research and development, the transient expression in human cell lines such as embryonic kidney (HEK 293), amniotic (CAP), a hybrid of HEK 293 and lymphoma (HKB-11), and embryonic retina (PER.C6) are favored over stable $\mathrm{CHO}$ expression due to the ease and speed of production of workable quantities of antibody for preliminary studies $[16,30-32,49,50]$. The generated $\mathrm{mAb}$ library undergoes relevant in vitro testing along with formulation stability screening to exclude candidates that have poor manufacturability attributes [51]. Lead $\mathrm{mAb}$ candidates that show potential for further investigation would then be developed for high yielding stable expression and more rigorous characterization leading up to therapeutic development. However, a drawback from changing from human to hamster expression systems is the difference in glycosylation profile. $\mathrm{CHO}$ expressed mAbs produce immunogenic non-human glycoform Neu5Gc and have a higher composition of sialylation, which may result in reduced antibody-dependent cellular cytotoxicity (ADCC). Therefore in the early stages of development, leads need to be identified and thoroughly characterized in the expression system to be developed for commercial manufacture before committing to industrial scale up [16,30,32]. Amongst other biotherapeutics, approved $\mathrm{mAb}$ Fc fusion therapeutics dulglutide (Trulicity ${ }^{\circledR}$, Eli Lilly, Indianapolis, IN USA), efmoroctocog alpha and eftrenonacog alpha (Eloctate ${ }^{\circledR}$ and Alprolix ${ }^{\circledR}$, Biogen, Cambridge, MA, USA), are manufactured in a HEK 293 expression system, which is giving rise to 
the acceptance of human-based expression systems for the production of mAb-based therapeutics [4]. However, HEK 293 expression systems are prone to inducing mAb aggregation in cultures, which is detrimental to cell viability and creates a loss of product during manufacture. Hence, HKB-11 and PER.C6 are the preferred commercial human cell lines for mAb expression in human cell lines, specifically $[16,31,32]$.

Established lower organism expression systems for fragment or recombinant fusion $\mathrm{mAb}$ therapeutics include bacteria such as E. coli, yeasts such as $S$. cerevisiae and P. pastoris, plants such as tobacco, algae, and insects such as silkworm [5,16,52-54]. Expression platforms that use E. coli in particular are considered high risk due to the potential endotoxin contamination in the mAb product, of which complete endotoxin removal requires further purification steps [19]. However, several approved $\mathrm{mAb}$ fragment- and recombinant-based therapies are produced in an E. coli-based expression system, including pegol conjugated Fab' certolizumab pegol (Cimzia ${ }^{\circledR}$, Celltech UCB, Brussels, Belgium), Fab ranibizumab (Lucentis ${ }^{\circledR}$, Genentech, San Francisco, CA, USA), and recombinant Fc fusion romiplostim (Nplate ${ }^{\circledR}$, Amgen, Thousand Oaks, CA, USA). Lower organism expression platforms such as E. coli and $P$. pastoris continue to be the preferred option for the manufacture of fragment $\mathrm{mAb}$ formats due to the relative ease, high yield, and reduced cost for manufacture as compared to mammalian expression platforms.

An emerging in vitro cell-free synthesis technology is being developed with bacterial and $\mathrm{CHO}$ cell lysates which have the potential to alleviate formation of undesirable biological byproducts, as the machinery from the cell lysates purely express protein from the mAb genes that are introduced to the system. Though this technology is not currently applicable for industrial scale manufacture, it holds much promise as an alternative to live culture. For instance, culture maintenance and highly defined media are no longer necessary, reactions can run continuously, lysates can be recycled with reproducible results, unmodified linear DNA is suitable for the system (thus alleviating a need for multiple cloning steps), and additional enzymes can be introduced to the system for the engineering of specific post-translational modifications [33,34,55-58]. Despite the apparent advantages of this technology for $\mathrm{mAb}$ manufacture, cell lysates encounter the same challenges as their host cell expression system. That is, post-translational modifications of $\mathrm{mAb}$ product from lysates from lower level organisms are limited by the endogenous machinery of that host organism. Furthermore, preparation of mammalian cell lysates is challenging, and yield produced from these lysates is considerably low $[59,60]$.

Current bioprocess engineering and cell line development strategies have been crucial in enhancing the manufacturability of mAbs. Many current mAb therapeutic expression platforms make use of $\mathrm{CHO}$ cell lines that have been commercially developed with dihydrofolate reductase or glutamine synthetase deficiency for enhanced stability selection through resistance to methotrexate and methionine sulfoximine inhibition, respectively [50,61]. Mammalian cell lines have been adapted to suspension culture, as they support higher cell densities and mAb titers in the absence of serum from the culture media, for large scale fed-batches, perfusion systems, or continuous culture systems. Further to this, cell lines are continually being engineered for enhanced metabolic functions, introducing glycosylation pathways, superior secretion, and resistance to apoptosis for prolonged survival, in efforts to generate super-producer cell lines that can sustain a continuous culture [62-68].

Gene and expression vector design and development are specifically tailored to the expression system to maximize mAb expression and cell line stabilization through host cell codon optimization and the addition of highly efficient transcription, secretion, selection, and integration elements [69-73]. Vectors can contain a single site for gene insertion for the subsequent co-transfection of vectors that carry the antibody heavy and light chains, or both chains can be cloned into a dual expression vector. In more elaborately designed recombinant $\mathrm{mAb}$ drug formats that require the expression of several genes, vector technologies have implemented multicistronic expression to enhance the efficiency of the vector system. The stable or transient transfection of vectors is performed on highly viable cell cultures with high cell density. Antibody heavy and light chain ratios may require adjustment in transfection for optimizing expression and secretion. A reporter vector that expresses green fluorescent protein is typically included 
to observe transfection efficiency during optimization [74,75]. Liposome-mediated transfection is preferential over all other mammalian transfection strategies and is induced chemically through the complexing of DNA to a cationic lipid prior to or during addition to a culture. Polyethylenimine is the most prevalently used transfection reagent despite the development of superior reagents such as Lipofectamine $^{\mathrm{TM}} 2000$ and Freestyle ${ }^{\mathrm{TM}} \mathrm{MAX}$ (Thermo Fisher Scientific, Waltham, MA, USA), LyoVec ${ }^{\mathrm{TM}}$ (InvivoGen, San Diego, CA, USA), FuGENE 6 ${ }^{\mathrm{TM}}$ (Promega, Madison, WI, USA), and TransIT-PRO ${ }^{\circledR}$ (Mirus, Madison, WI, USA), owing to its lower cost and relative efficiency [73,75-78].

The commercial manufacture of $\mathrm{mAbs}$ has transitioned to serum-free, chemically defined, and animal-free media which has removed a source of expression variability and has been driven particularly from the advent of mad cow disease $[50,79]$. Several media supplements such as plant and yeast digests (peptones/hydrolysates), surfactants (e.g., Pluronic F-68), DNA methyltransferase (azacytidine), and histone deacetylase (sodium butyrate, valproic acid) inhibitors have been found to support cell viability and enhance $\mathrm{mAb}$ expression [79-85]. Mild hypothermia of the culture has also demonstrated to reduce cell expansion, support prolonged cell viability, and enhance mAb expression [73,86-90]. Further to this, continuous supplementation in expression cultures of uridine, manganese chloride, and galactose demonstrated successful the glycan engineering of expressed $\mathrm{mAb}$, where $\mathrm{mAb}$ hyper-galactosylation was promoted to enhance complement-dependent cytotoxicity (CDC) activity [91].

In the manufacturing process of fed-batch, perfusion, and continuous culture systems, media is continuously fed in the culture system, whilst parameters such as cell viability, cell density, and metabolite levels are monitored in real time until the parameters indicate that it is the optimal time to harvest the expressed $\mathrm{mAb}$ from the culture supernatant. In perfusion and continuous culture systems, a feed is removed from the culture simultaneously to the media addition, the difference being that the cell dilution rate in continuous culture is optimized to remain equal or higher than the cell growth rate, which allows the perpetuation of $\mathrm{mAb}$ expression and requires the continuous harvest of the supernatant [92-94]. The harvest of the supernatant requires clarification technologies such as the use of precipitants/flocculants (e.g., polyethylene glycol, diethylaminoethyl dextran, caprylic acid, and polyethylenimine), high throughput centrifugation, and filtration methods to remove cells and biological debris, for the lowering the loading burden in the lead up to mAb capture through affinity chromatography [19,95-100]. The mechanical stresses from centrifugation and filtration are unavoidable, although they can induce mild $\mathrm{mAb}$ product loss through fragmentation and aggregation.

Protein A-ligand-based affinity chromatography is the most robust, efficient, and prevalently used mAb capture technology, owing to its selectivity and high affinity to various human Fc, as well as its efficient dissociation of captured $\mathrm{mAbs}$ at a low $\mathrm{pH}$ for reuse. Fragment mAbs and recombinant formats based on Fabs and single chain variable fragments ( $\mathrm{scFv}$ ) are unable to take advantage of protein A affinity capture, and alternatives have been developed, such as capturing proteins $G$, $\mathrm{M}$, and L, which bind at different mAb epitopes; ion exchange chromatography; and polyhistidine tagged capture through immobilized metal chromatography [100-102]. A further advantage of affinity chromatography in manufacture is the integration of a viral inactivation step by holding the low $\mathrm{pH}$-eluted $\mathrm{mAb}$ product prior to further purification steps; however, this applies the mAb product to low $\mathrm{pH}$ at high concentrations, which can induce mild mAb instability, aggregation, and the formation of acidic variants $[5,22,100,103,104]$.

Post $\mathrm{mAb}$ capture, further polishing steps are required to remove further contaminants such as host cell proteins and DNA, as well as leached affinity chromatography ligand- and mAb-degradation products such as fragments, aggregates, and ionic variants. The polishing steps are designed based on the specific properties of the mAb product, such as the isoelectric point and molecular weight (MW), to implement appropriate chromatographic technologies such as anion and cation exchanges, hydrophobic interaction, and multimodal and size exclusion that will separate the mAb product from the manufacture-introduced impurities [22,100,103]. The additional chromatographic steps unavoidably apply the mAb product to buffers of varying ionic strength and high concentrations, which can again induce mild mAb instability and aggregation. Post polishing steps, the purified 
$\mathrm{mAb}$ product undergoes a further viral removal step, such as filtration, and then it undergoes buffer exchange and concentration through ultrafiltration or diafiltration methods to prepare the bulk $\mathrm{mAb}$ product for formulation [100,105].

\section{Formulation Strategies and Considerations}

Strategies to improve the formulation of $\mathrm{mAbs}$ and $\mathrm{mAb}$-based therapies continues to be an ongoing challenge, as is faced with all biotherapeutics. Firstly, whole therapeutic mAbs are unsuitable for non-invasive oral, nasal, or pulmonary routes of administration as they are susceptible to chemical and enzymatic degradation in the gastrointestinal tract. The bioavailability of mAbs through these routes is poor, owing to mAbs' polar surface charge and relatively large MW, limiting transport through mucosal membranes.

Fragment $\mathrm{mAb}$ platforms, together with excipient and PEGylation technologies, have been developed to help circumvent transportation limitations for pulmonary delivery, specifically. However, physical stresses applied to the mAb (e.g., shear stresses from the aerosolization of liquid formulations for a pressurized meter dose and a nebulization delivery, or from the production of dry powder for inhalation) pose further challenges of $\mathrm{mAb}$ instability, leading to degradation and reduced efficacy. $[8,26,28]$. Few biologics have been successfully approved for pulmonary delivery, most notably insulin formulation Afrezza ${ }^{\circledR}$ (MannKind, Westlake Village, CA, USA), and, currently, an erythropoietin-Fc fusion and a nanobody-targeting respiratory syncytial virus are in clinical trials, showing promise for the further development of this administration strategy for both the systemic and localized delivery of mAb-based therapeutics [5,28].

Several drug carrier technologies such as microencapsulation, liposome, and nanoparticle formulations inherently enhance the stability and control the release of mAbs, which can prolong their half-life. These nanocarrier formulation strategies are of intense interest, as they hold promise for developing less invasive inhaled formulations of mAb-based therapeutics with superior attributes to currently established formulations [41,106-109].

The majority of currently approved $\mathrm{mAb}$ therapeutics are formulated for IV, although commercial interest has directed technologies to develop injectable $\mathrm{mAb}$ formulations which has seen success in many approved $\mathrm{mAb}$ therapies thus far, primarily SC for systemic delivery, along with a few intravitreal and intramuscular formulations for tissue-specific indications. Amongst others, anti-HER2 antibody trastuzumab was originally developed as an IV formulation and was successfully repurposed as a SC formulation [110-112], whereas next generation therapies have directly moved towards SC formulation, such as with anti-TNF- $\alpha$ antibody adalimumab [113]. Injectable administrations offer several advantages over IV administration, especially in the treatment of chronic diseases in regards to a reduced burden to allied health services, patient tolerance, and adherence to treatment; however, the intrinsic physicochemical properties of mAbs may be undesirable for injectable formulation. In considering the low volume, injection pressure, and the typically high (>100 mg) effective dose of $\mathrm{mAb}$ for injectable delivery, the viscosity and aggregation propensity of mAbs become key formulation challenges to address, as they are dependent on mAb concentration. Certain $\mathrm{mAb}$ therapies are suitable, and others are not based on their solubility, viscosity, self-association, intrinsic stability, aggregation, and precipitation profiles.

Injectable $\mathrm{mAb}$ formulations can be further improved with the use of excipients to increase solubility, reduce viscosity, and enhance the stability of mAbs. Excipients are considered for a formulation based on their physicochemical properties, pharmacokinetics, and safety. For example, polysorbates are commonly used in biologics as a stabilizing agent; however, their addition in high concentrations can denature proteins and cause adverse side effects such as injection site reactions [114-116]. Injectable $\mathrm{mAb}$ formulations are co-formulated with recombinant human hyaluronidase, specifically as a permeation enhancer for more efficient absorption into tissue, although the inclusion of this additional biologic adds further burden to the formulation's viscosity and propensity to aggregate [5,8,25-28,117-123]. Antibody therapies for IV administration are prepared as 
lyophilised powder for reconstitution and further dilution, and injectable administrations are prepared as liquid-based formulations in pre-filled syringes. Liquid formulations of mAbs are more susceptible to physiochemical degradation, are less stable, and have a reduced shelf-life as compared to lyophilised formulations. However, drying technologies to produce lyophilised formulations apply the mAb to physical stresses that induce instability and degradation, leading to reduced efficacy [124-126].

Long-term stability predictions are elucidated from formulation screening in accelerated aggregation studies, as part of the preliminary screening process of generated $\mathrm{mAb}$ libraries [127]. The stability profiles of mAbs can be greatly affected by the amino acid composition, structure, and potential glycosylation in their variable region CDRs that are isolated through the screening and maturation process. Elucidating the causes for reduced solubility or increased aggregation propensity has to be considered together with the molecular interactions between the mAb and the biological target as to not compromise affinity. Computational tools have been developed to elucidate amino acids within the $\mathrm{mAb} C D R$ structure that have a high propensity to aggregate, and strategies for improving solubility and aggregation profiles have been developed through direct amino acid substitutions and the strategic addition of glycosylation sites [128-132]. The characterization of mAb stability and target interaction for optimization is considered a fundamental step as part of preliminary drug discovery, as the applicability for development, manufacture, and formulation of the mAb therapeutic is governed by the mAbs stability profile.

\section{Improving mAb Tissue Penetration for Cancer Treatment}

Antibody therapies are currently restricted to invasive parenteral routes of administration for maximum bioavailability and systemic distribution; however, delivery to the specific target tissue, such as tumors for cancer treatments, continues to be a challenge. Penetration to tissue from blood vessels is again poor, owing to $\mathrm{mAbs}^{\prime}$ polar surface charge and relatively large MW, limiting transport through physiological barriers. The efficiency of tissue penetration is further influenced by systemic and local $\mathrm{mAb}$ clearance rates. Enhancement to $\mathrm{mAbs}^{\prime}$ affinity to their biological target through maturation and strategic mutation technologies have led to faster diffusion rates of $\mathrm{mAb}$ to target for increased efficacy. However, for tumourous tissue specifically, penetration through tumors is restricted by the tumor's binding site barrier, in which antigens expressed on the tumors periphery capture the majority of the $\mathrm{mAb}$ released to surrounding tissue; this effect is exaggerated with overexpressed antigen. The enhancement of whole mAbs' affinity beyond $1 \mathrm{nM}$ has specifically shown that there is no further improvement of tumor diffusion rates, tissue penetration, and accumulation $[42,43,133]$. An increased affinity of mAbs to cellular targets also leads to the increased uptake, internalization, and catabolism of mAbs, which reduces ADCC and increases the $\mathrm{mAb}$ clearance rate. This mechanism is exploited through the development of high affinity ADCs to target the delivery and release of potent drugs, inducing targeted cell death [43-45].

Fragment $\mathrm{mAb}$ platforms have shown better tissue penetration and biodistribution than whole $\mathrm{mAb}$ therapeutics; however, a pitfall of smaller peptides lacking an Fc region is a highly reduced in vivo half-life and poor retention times. Technologies to improve the half-life of $\mathrm{mAb}$ fragments have been primarily through PEGylation, along with strategic Fc mutation and glycosylation engineering to enhance neonatal $F_{c}$ receptor $\left(F_{c} R n\right)$ recycling. Furthermore, hyper-glycosylation technology has been successfully applied in other biotherapeutics, such as with glycosylated erythropoietin Aranesp ${ }^{\circledR}$ (Amgen, Thousand Oaks, CA, USA). Conversely, nanocarrier platforms that are relatively larger as compared to whole mAbs have demonstrated superior pharmacokinetics and tumor retention, as well as previously mentioned enhanced stability and the sustained, controlled release of mAbs [41]. These enhanced properties have generated considerable interest in developing the systemic delivery of mAb-nanoparticle platforms for superior tumor penetration, as well as targeted and sustained therapeutic drug delivery. Further to nanocarriers, additional formulation strategies developed for the controlled release of mAbs include hydrogels and crystalline antibodies, which have shown success as stable, injectable formulations for development [5,8,15,41-43,134-136]. 
In addition, to further enhance the stability and half-life of other biotherapeutics, recombinant technologies allowed their fusion to $\mathrm{mAb}$ Fc as to introduce FcRn recycling as a protection mechanism, which has innovatively expanded the applicability of mAb-based therapeutic platforms. Notable examples include the TNF Receptor-Fc fusion protein Enbrel ${ }^{\circledR}$ (Amgen, Thousand Oaks, CA, USA), which acts as an inhibitor to overexpressed TNF- $\alpha$ in autoimmune diseases, and the Factor IX-FC fusion protein Alprolix ${ }^{\circledR}$ (Biogen, Cambridge, MA, USA), which is a blood factor supplement for hemophiliacs $[11,46,133]$.

\section{Strategic Modulation of mAb Immune Effector Functions}

The modulation of mAbs effector functions through isotype switching, glycoengineering, and strategic mutations have proved advantageous for the development of more effective mAb treatment strategies. Antibody binding to $\mathrm{Cq} 1$ promotes the complement cascade, $\mathrm{Fc}_{\gamma} \mathrm{R} 1 \mathrm{~A} / \mathrm{B}, \mathrm{Fc}_{\gamma} \mathrm{R} 2 \mathrm{~A}$, and $\mathrm{Fc}_{\gamma} \mathrm{R} 3 \mathrm{~A} / \mathrm{B}$ receptors to activate immune effector functions; $\mathrm{Fc}_{\gamma} \mathrm{R} 2 \mathrm{~B}$ counter-balances the effector response, and $\mathrm{FcRn}$ prolongs $\mathrm{mAb}$ half-life. Binding to these receptors is primarily done through sites in the $C_{\text {hinge }}, C_{H}$, and the conserved glycosylation region in the $F_{C}(\mathrm{~N} 297)$.

IgG3 does not efficiently bind to FcRn, which reduces its half-life to approximately seven days, as opposed to a 21 day half-life for the other IgG isotypes. In most instances of mAb design, an extended half-life is preferred as to prolong the effective dose of a mAb in serum [15]. IgG2 and IgG4 mAbs have a reduced effector function as compared to IgG1 and are thus used in instances where minimal engagement to the immune system is warranted to increase safety of the mAb therapy-with ADCs reducing off-target cytotoxicity, for instance. Eculizumab (Soliris ${ }^{\circledR}$, Alexion Pharmaceuticals, New Haven, CT, USA) is the first (and thus far only) approved recombinant IgGk $2\left(\mathrm{C}_{\mathrm{H}} 1 / \mathrm{C}_{\text {hinge }}\right)-4\left(\mathrm{C}_{\mathrm{H}} 2 / \mathrm{C}_{\mathrm{H}} 3\right)$ hybrid whole $\mathrm{mAb}$. Further cross-sub-class variant $\mathrm{mAb}$ therapies are in development, with key amino acid substitutions from the IgG2 and IgG4 sub-classes introduced for intentionally suppressed effector functions $[4,13]$. The removal of the conserved glycosylation site through amino acid substitution of N297 or T299 (aglycosylation) has also demonstrated reduced effector function; however, this happens at the expense of mAb stability and is therefore not a suitable strategy for whole $\mathrm{mAb}$ therapeutics [11,14,15,137-140].

On the other hand, enhancing ADCC and CDC is useful for engaging the immune system to tumor tissues in the absence of a conjugated cytotoxic drug. Certain glycoengineered modifications to the conserved glycosylation region in the Fc, such as deficiency in core fucose (afucosylation) and hyper-galactosylation, have demonstrated enhanced $\mathrm{mAb}$ binding to $\mathrm{Fc}_{\gamma} \mathrm{R} 3 \mathrm{~A}$ and $\mathrm{Cq} 1$, specifically for an enhanced ADCC and CDC effect $[13,43]$. Afucosylated mAbs benralizumab (Fasenra ${ }^{\mathrm{TM}}$, AstraZeneca, London, UK) and mogamulizumab (Poteligeo ${ }^{\circledR}$, Kyowa Hakko Kirin, Tokyo, Japan), as well as low fucose content mAb obinutuzumab (Gazyva ${ }^{\circledR}$, Genentech, San Francisco, CA, USA), are currently approved therapies, with several further in development (along with clinical trials), which demonstrates the commercial interest and applicability of this technology in improving $\mathrm{mAb}$ therapeutics through enhancing ADCC. However, the significance of manipulating sialylation in $\mathrm{mAb}$ therapeutics is a controversial topic, with several reports demonstrating a reduction in ADCC and CDC and others reporting no observable difference. This highlights a clear need to characterize and define the in vivo efficacy of such manipulation $[11,13,14,43]$.

No currently approved $\mathrm{mAb}$ therapies contain amino acid substitutions for an improved half-life through modulated binding properties to FCRn, improved CDC through binding to complement factor Cq1, or improved ADCC through enhanced binding affinity to $\mathrm{Fc}_{\gamma} \mathrm{R} 1 \mathrm{~A}$ and $3 \mathrm{~A}$. However, several mutations have been reported, patented, and are in clinical development, demonstrating the commercial interest in this technology for improving mAb therapeutics [6,11,13,15,133,137,140-143].

For a more comprehensive understanding of $\mathrm{mAb}$ engineering strategies for modulated immune effector functions, we direct the reader to the following reviews [13-15,140]. 


\section{Computational Approaches for Aggregation Prediction and Rational Design of mAbs}

The advancement of in silico analysis of mAb peptide sequences, structures, conformation, and their associated biological interaction has been integral to the development of various computational tools for characterizing, designing, and optimizing mAb-based therapeutics. The generation and continued pursuit of $\mathrm{mAb}$ structural data for in silico analysis has led to the development of several integral databases, notably IMGT ${ }^{\circledR}$, serving as a key resource for data mining [144-146]. Molecular dynamic (MD) simulation analysis has driven the computational analysis of the discovery and characterization of relevant molecular interactions within the $\mathrm{mAb}$ molecule, $\mathrm{mAb}$ binding to biological targets and $\mathrm{mAb}$ surface association with the surrounding environment. These interactions can infer intrinsic stability, target binding associations, solubility and aggregation propensity of the mAb. MD simulations and free energy calculations from crystal structures remain key for the highly specific elucidation of mAb-target intermolecular interactions that correlate to binding affinity, as significant interactions such as hydrogen-bond formation can be predicted and determine the strength of the molecular associations [147]. However, elucidation of mAb self-association, solubility, and aggregation propensity have been driven by the development of computational modelling and simulation tools that simultaneously analyses mAb topography and surface polarity. Notably, AGGRESCAN3D, TANGO, and PASTA are the most prominent tools for predicting the site specific aggregation propensity of mAbs [35,148].

The preliminary elucidation of $\mathrm{mAb}$ structural data-that being amino acid sequences and higher order structure (HOS) - is experimentally derived to produce crystal structures that model the solid-state 3D structure of the mAb. Mass spectrometry technologies have come of age to produce high throughput and orthogonal analysis to elucidate $\mathrm{mAb}$ peptide sequences, oxidation, deamidation, and glycosylation heterogeneity, as well as, more recently, for native, destabilized, and aggregated HOS elucidation $[149,150]$. X-ray crystallography technologies have been the underlying workhorse for elucidating the crystal structure of mAbs. Producing crystalline mAbs is challenging, owing to the complexity of $\mathrm{mAb} \mathrm{HOS}$ and the degree of $\mathrm{mAb}$ conformational heterogeneity. However, several complementing technologies have evolved in recent years to ascertain structure and interactions, including circular dichroism (CD), infrared (IR) and raman spectroscopy, cryogenic-electron microscopy, and nuclear magnetic resonance (NMR) spectroscopy [148,150-157]. Of the technologies available for HOS elucidation, 2D-NMR and X-Ray crystallography (followed by MS) provide the highest sensitivity and local specificity. In comparison, CD, IR, and raman are high-throughput methods, although they have much lower sensitivity $[150,157]$.

Thus far, only four whole IgG antibodies have a successfully determined crystal structure (PDB ID: 1HZH, 1IGT, 1IGY, and 5DK3), notably 1HZH as a wholly human IgG1 and 5DK3 as a humanized $\operatorname{IgG} / /$, both of which have been used as model structures for MD simulations [158]. However, fragment mAbs yield much higher success with producing crystal structures, which has led to much pursuit and contribution in generating $\mathrm{mAb}$ fragments and targetting complexing crystal structure libraries for data mining and in silico analysis $[159,160]$.

Upon obtaining relevant crystal structures for a candidate $\mathrm{mAb}$, detailed crystal structure and MD simulation analysis has been extensively used to elucidate the $\mathrm{mAbs}$ intramolecular interactions that confer intrinsic stability and intermolecular interactions to confer interactions to biological targets and self-association. The particular binding interface of interest is analyzed, and amino acids in the $\mathrm{mAb}$ structure are identified for substitution that can disrupt molecular interactions in the interface in the instance of diminishing target binding and identify potentially unutilized bonding sites and polarity mismatches in the interface that can be improved in the instance of enhancing target binding. MD simulations are then carried out for the native and substituted $\mathrm{mAb}$ structures to elucidate any relevant bond formations, interactions, and more favorable binding free energy produced by the substituted structure, of which promising candidates can be synthesized and validated through in vitro analysis. This predictive approach has been successfully applied to identify mutations in mAbs for modulating effector functions, target binding, optimizing affinity capture for manufacturing, and, more 
recently, for designing antibodies de novo from targets of interest [11,161-165]. Mutations have been specifically identified for enhanced binding to $\mathrm{Fc}_{\gamma} \mathrm{R} 2 \mathrm{~A}, \mathrm{Fc}_{\gamma} \mathrm{R} 3 \mathrm{~A}$, and $\mathrm{Cq} 1$, as well as a reduced binding to $\mathrm{Fc}_{\gamma} \mathrm{R} 2 \mathrm{~B}$ for a more pronounced $\mathrm{ADCC}$ and $\mathrm{CDC}$ effect, an enhanced binding to $\mathrm{FcRn}$ for an extended half-life, and a reduced binding to $\mathrm{FC}_{\gamma}$ Rs and $\mathrm{Cq} 1$ for a diminished $\mathrm{ADCC}$ and $\mathrm{CDC}$ effect, all of which are transferrable to $\mathrm{mAbs}$ of the same isotype sub-class $[137,141,142]$. Further to this, the molecular interactions of glycoengineered $\mathrm{mAb}$ variants to $\mathrm{FcRs}$ have been characterized through MD simulations to corroborate predictions with the observed modulated effector functions $[13,15,137,141,142]$.

Self-association, solubility, and aggregation propensity are further evaluated by computational modelling tools that specifically characterize the topography and surface polarity of mAbs, concurrently analyzing the local spatial arrangement of amino acids in the mAb structure, solvent accessibility, and local surface charge [5]. In particular, surface exposed hydrophobicity is sought as the lead mechanism for protein self-association driving aggregation propensity, in which aggregation-prone regions (APRs) are identified in the mAb structure. The substitution of identified APRs to gatekeeper (i.e., polar) amino acids has experimentally demonstrated resistance to aggregation and improved solubility, which validates this strategy for improving mAb stability [36-40,166-170]. The majority of APRs identified are located in biologically relevant $\mathrm{mAb}$ regions-those being the CDRs and the Fc. Specifically targeting these APRs through mutation may disrupt important biological functions and $\mathrm{mAb}$ structure. Analyses of the mAbs intermolecular interactions are necessary to validate the intrinsic stability of substituted $\mathrm{mAb}$ variants; if conformational fluctuations are elucidated, then the biologically active interface is likely disrupted. Interestingly, mutations for enhancing biological functions have demonstrated a negative impact on $\mathrm{mAb}$ solubility and stability, further suggesting that the self-association profile of mAbs is linked to its biological activity [36,128,171].

Aside from direct residue substitution in $\mathrm{mAb}$ structures, other strategies reported to profoundly interfere with the effects of APRs include isotype switching and the strategic addition of N-linked glycans $[39,128,172,173]$. Additionally, N-linked glycosylation in the CDR regions of mAbs, although uncommon, has demonstrated improved solubility and stability profiles of mAbs without impacting their target affinity, as compared to the same mAbs with removed CDR glycans [128,174]. The rationale behind strategic glycan addition is based on the election of N-linked glycosylation sites that have apparent spacial proximity to APRs, with the introduced glycan therefore sterically hindering the APR from self-association interactions. The benefits of extending $\mathrm{mAb}$ half-life with strategic glycan addition, as seen with hyper-glycosylated biotherapeutics (as well as improving mAb solubility and stability for improved formulation strategies) has yet to be realized and suggests a very intriguing and highly relevant technology for perusal.

\section{Concluding Remarks}

Therapeutic antibodies have come of age as continuing to be a key, dominant technology in the biopharmaceutical industry. The repurpose of antibodies to many formats have made them versatile to design and tailor highly specialized treatments, including ADCs as a targeted drug delivery system, bispecific and fragment $\mathrm{mAb}$ platforms for tailored engagement and increased bioavailability, and recombinant $\mathrm{Fc}$-fusion proteins for an increased half-life and introduced immunological engagement. Further advancements include the modulation of Fc effector functions through manipulations of the Fc, either through isotype switching, glycoengineering, or strategic mutations in the Fc region, along with the PEGylation of fragment mAbs for enhanced half-life. Advancements in discovery, manufacture, and formulation technologies have further propelled the success of therapeutic antibodies, notably through expression system development and the transition from IV to SC formulations. Human-based expression systems have been extensively used in $\mathrm{mAb}$ development and are becoming an accepted manufacturing platform for $\mathrm{mAb}$ therapeutics. Furthermore, cell-free synthesis technology is giving rise to the potential for higher efficiency in the manufacture process.

Though developments for further generation antibody therapies have led to great strides in producing improved therapeutic outcomes, many facets of the manufacture process and formulation 
development strategy pose as challenges to be considered. Antibody-based therapies are susceptible to chemical and enzymatic degradation through oral, nasal, or pulmonary routes of administration and are therefore currently restricted IV or SC delivery. Despite achieving maximum bioavailability through IV/SC administration, tissue penetration of $\mathrm{mAb}$-based therapies is poor, which limits their local bioavailability, requiring high concentrations to achieve an effective dose. The stability of mAbs-based therapeutics is a highly pronounced and recurring challenge to be considered, as it affects manufacture yield and formulation considerations. Several strategies are in development to improve the stability of mAbs in order to potentially produce formulations for pulmonary or oral administration. Notably, computational tools have come of age, complementing experimental techniques to derive antibody structure and aggregation prediction. Through these methods, the stability and aggregation propensity of $\mathrm{mAb}$-based therapies have demonstrated improvement through rational mutation and glycosylation within the framework region, which is potentially translatable to all mAbs within the same isotype. Furthermore, nanocarrier technologies have been shown to enhance the stability and potentially control the release of $\mathrm{mAbs}$. The refinement of rational $\mathrm{mAb}$ design coupled with nanocarrier technologies has the potential to overcome these challenges, to develop superior treatment strategies, and ultimately to formulate for non-invasive administration routes such as pulmonary delivery.

Author Contributions: V.S. revised the figure and prepared the scope, literature review, and original manuscript draft. E.C prepared the original figure and reviewed the manuscript. B.E. and V.K. equally reviewed and edited the manuscript.

Funding: This research received no external funding.

Conflicts of Interest: The authors declare no conflict of interest.

\section{References}

1. Urquhart, L. Top drugs and companies by sales in 2017. Nat. Rev. Drug Discov. 2018, 17, 232. [CrossRef] [PubMed]

2. Ecker, D.; Dana Jones, S.; Levine, H.L. The therapeutic monoclonal antibody market. $m A b s$ 2015, 7, 9-14. [CrossRef] [PubMed]

3. An, Z. "Magic bullets" at the center stage of immune therapy: A special issue on therapeutic antibodies. Protein Cell 2018, 9, 1-2. [CrossRef] [PubMed]

4. Santos, M.L.d.; Quintilio, W.; Manieri, T.M.; Tsuruta, L.R.; Moro, A.M. Advances and challenges in therapeutic monoclonal antibodies drug development. Bras. J. Pharm. Sci. 2018, 54. [CrossRef]

5. Elgundi, Z.; Reslan, M.; Cruz, E.; Sifniotis, V.; Kayser, V. The state-of-play and future of antibody therapeutics. Adv. Drug Del. Rev. 2017, 122, 2-19. [CrossRef]

6. Almagro, J.C.; Daniels-Wells, T.R.; Perez-Tapia, S.M.; Penichet, M.L. Progress and challenges in the design and clinical development of antibodies for cancer therapy. Front. Immunol. 2018, 8, 1751. [CrossRef] [PubMed]

7. Liu, B.N.; Luo, J.H. Research and development of innovative antibody-based drugs. Yaoxue Xuebao 2017, 52, 1811-1819.

8. Awwad, S.; Angkawinitwong, U. Overview of antibody drug delivery. Pharmaceutics 2018, 10, 83. [CrossRef] [PubMed]

9. Klein, C. Special issue: Monoclonal antibodies. Antibodies 2018, 7, 17. [CrossRef]

10. Wang, C.; Xu, P.; Zhang, L.; Huang, J.; Zhu, K.; Luo, C. Current strategies and applications for precision drug design. Front. Pharmacol. 2018, 9, 787. [CrossRef] [PubMed]

11. Strohl, W.R. Current progress in innovative engineered antibodies. Protein Cell 2018, 9, 86-120. [CrossRef] [PubMed]

12. Hoffmann, R.M.; Coumbe, B.G.T.; Josephs, D.H.; Mele, S.; Ilieva, K.M.; Cheung, A.; Tutt, A.N.; Spicer, J.F.; Thurston, D.E.; Crescioli, S.; et al. Antibody structure and engineering considerations for the design and function of antibody drug conjugates (adcs). OncoImmunology 2018, 7, e1395127. [CrossRef] [PubMed]

13. Wang, X.; Mathieu, M.; Brezski, R.J. Igg fc engineering to modulate antibody effector functions. Protein Cell 2018, 9, 63-73. [CrossRef] [PubMed] 
14. Pawlowski, J.W.; Bajardi-Taccioli, A.; Houde, D.; Feschenko, M.; Carlage, T.; Kaltashov, I.A. Influence of glycan modification on igg1 biochemical and biophysical properties. J. Pharm. Biomed. Anal. 2018, 151, 133-144. [CrossRef] [PubMed]

15. Fonseca, M.H.G.; Furtado, G.P.; Bezerra, M.R.L.; Pontes, L.Q.; Fernandes, C.F.C. Boosting half-life and effector functions of therapeutic antibodies by fc-engineering: An interaction-function review. Int. J. Biol. Macromol. 2018, 119, 306-311. [CrossRef] [PubMed]

16. Mizukami, A.; Caron, A.L.; Picanço-Castro, V.; Swiech, K. Platforms for recombinant therapeutic glycoprotein production. In Recombinant Glycoprotein Production; Humana Press Inc.: New York, NY, USA, 2018; Volume 1674, pp. 1-14.

17. Thomson, C.A. Igg structure and function. In Encyclopedia of Immunobiology; Elsevier Inc.: Amsterdam, The Netherlands, 2016; Volume 2, pp. 15-22.

18. Kayser, V.; Chennamsetty, N.; Voynov, V.; Forrer, K.; Helk, B.; Trout, B.L. Glycosylation influences on the aggregation propensity of therapeutic monoclonal antibodies. Biotechnol. J. 2011, 6, 38-44. [CrossRef]

19. Pieracci, J.P.; Armando, J.W.; Westoby, M.; Thommes, J. Chapter 9-Industry review of cell separation and product harvesting methods. In Biopharmaceutical Processing; Jagschies, G., Lindskog, E., Łacki, K., Galliher, P., Eds.; Elsevier: Amsterdam, The Netherlands, 2018; pp. 165-206.

20. Huang, C.-J.; Lin, H.; Yang, X. Industrial production of recombinant therapeutics in escherichia coli and its recent advancements. J. Ind. Microbiol. Biotechnol. 2012, 39, 383-399. [CrossRef]

21. Behme, S. Manufacturing of Pharmaceutical Proteins: From Technology to Economy: Second, Revised and Expanded Edition; Wiley: Hoboken, NJ, USA, 2015; pp. 1-427.

22. Ulmer, N.; Vogg, S.; Müller-Späth, T.; Morbidelli, M. Chapter 7-Purification of human monoclonal antibodies and their fragments. In Human monoclonal Antibodies: Methods and Protocols; Steinitz, M., Ed.; Springer: New York, NY, USA, 2019; pp. 163-188.

23. Arosio, P.; Barolo, G.; Müller-Späth, T.; Wu, H.; Morbidelli, M. Aggregation stability of a monoclonal antibody during downstream processing. Pharm. Res. 2011, 28, 1884-1894. [CrossRef]

24. Kayser, V.; Chennamsetty, N.; Voynov, V.; Helk, B.; Trout, B.L. Conformational stability and aggregation of therapeutic monoclonal antibodies studied with ans and thioflavin $\mathrm{t}$ binding. $m A$ s s 2011, 3, 408-411. [CrossRef]

25. Bittner, B.; Richter, W.; Schmidt, J. Subcutaneous administration of biotherapeutics: An overview of current challenges and opportunities. Biodrugs 2018, 32, 425-440. [CrossRef]

26. Viola, M.; Sequeira, J.; Seiça, R.; Veiga, F.; Serra, J.; Santos, A.C.; Ribeiro, A.J. Subcutaneous delivery of monoclonal antibodies: How do we get there? J. Control. Release 2018, 286, 301-314. [CrossRef] [PubMed]

27. Otvos, L. 6.05-Basic principles of formulation for biotherapeutics: Approaches to alternative drug delivery. In Comprehensive Medicinal Chemistry III; Chackalamannil, S., Rotella, D., Ward, S.E., Eds.; Elsevier: Oxford, UK, 2017; pp. 131-156.

28. Morales, J.O.; Fathe, K.R.; Brunaugh, A.; Ferrati, S.; Li, S.; Montenegro-Nicolini, M.; Mousavikhamene, Z.; McConville, J.T.; Prausnitz, M.R.; Smyth, H.D.C. Challenges and future prospects for the delivery of biologics: Oral mucosal, pulmonary, and transdermal routes. AAPS J. 2017, 19, 652-668. [CrossRef] [PubMed]

29. Muheem, A.; Shakeel, F.; Jahangir, M.A.; Anwar, M.; Mallick, N.; Jain, G.K.; Warsi, M.H.; Ahmad, F.J. A review on the strategies for oral delivery of proteins and peptides and their clinical perspectives. Saudi Pharm. J. 2016, 24, 413-428. [CrossRef] [PubMed]

30. Hunter, M.; Yuan, P.; Vavilala, D.; Fox, M. Optimization of protein expression in mammalian cells. Curr. Protoc. Protein Sci. 2019, 95, e77. [CrossRef] [PubMed]

31. Lindskog, E.K.; Fischer, S.; Wenger, T.; Schulz, P. Chapter 6-Host cells. In Biopharmaceutical Processing; Jagschies, G., Lindskog, E., Łącki, K., Galliher, P., Eds.; Elsevier: Amsterdam, The Netherlands, 2018; pp. 111-130.

32. Fliedl, L.; Grillari, J.; Grillari-Voglauer, R. Human cell lines for the production of recombinant proteins: On the horizon. New Biotechnol. 2015, 32, 673-679. [CrossRef]

33. Matsuda, T.; Ito, T.; Takemoto, C.; Katsura, K.; Ikeda, M.; Wakiyama, M.; Kukimoto-Niino, M.; Yokoyama, S.; Kurosawa, Y.; Shirouzu, M. Cell-free synthesis of functional antibody fragments to provide a structural basis for antibody-antigen interaction. PLoS ONE 2018, 13, e0193158. [CrossRef]

34. Stech, M.; Kubick, S. Cell-free synthesis meets antibody production: A review. Antibodies 2015, 4, 12. [CrossRef] 
35. Pujols, J.; Peña-Díaz, S.; Ventura, S. Aggrescan3d: Toward the prediction of the aggregation propensities of protein structures. In Methods Mol. Biol.; Humana Press Inc.: New York, NY, USA, 2018; Volume 1762, pp. 427-443.

36. Van der Kant, R.; Karow-Zwick, A.R.; Van Durme, J.; Blech, M.; Gallardo, R.; Seeliger, D.; Aßfalg, K.; Baatsen, P.; Compernolle, G.; Gils, A.; et al. Prediction and reduction of the aggregation of monoclonal antibodies. J. Mol. Biol. 2017, 429, 1244-1261. [CrossRef]

37. Lerch, T.F.; Sharpe, P.; Mayclin, S.J.; Edwards, T.E.; Lee, E.; Conlon, H.D.; Polleck, S.; Rouse, J.C.; Luo, Y.; Zou, Q. Infliximab crystal structures reveal insights into self-association. $m A$ ss 2017, 9, 874-883. [CrossRef]

38. Dobson, C.L.; Devine, P.W.A.; Phillips, J.J.; Higazi, D.R.; Lloyd, C.; Popovic, B.; Arnold, J.; Buchanan, A.; Lewis, A.; Goodman, J.; et al. Engineering the surface properties of a human monoclonal antibody prevents self-association and rapid clearance in vivo. Sci. Rep. 2016, 6, 38644. [CrossRef]

39. Courtois, F.; Agrawal, N.J.; Lauer, T.M.; Trout, B.L. Rational design of therapeutic mabs against aggregation through protein engineering and incorporation of glycosylation motifs applied to bevacizumab. mAbs 2016, 8, 99-112. [CrossRef]

40. Courtois, F.; Schneider, C.P.; Agrawal, N.J.; Trout, B.L. Rational design of biobetters with enhanced stability. J. Pharm. Sci. 2015, 104, 2433-2440. [CrossRef]

41. Yu, M.; Wu, J.; Shi, J.; Farokhzad, O.C. Nanotechnology for protein delivery: Overview and perspectives. J. Control. Release 2016, 240, 24-37. [CrossRef]

42. Shi, J.; Kantoff, P.W.; Wooster, R.; Farokhzad, O.C. Cancer nanomedicine: Progress, challenges and opportunities. Nat. Rev. Cancer 2016, 17, 20. [CrossRef]

43. Dalziel, M.; Beers, S.A.; Cragg, M.S.; Crispin, M. Through the barricades: Overcoming the barriers to effective antibody-based cancer therapeutics. Glycobiology 2018, 28, 697-712. [CrossRef]

44. Lambert, J.M.; Berkenblit, A. Antibody-drug conjugates for cancer treatment. Annu. Rev. Med. 2018, 69, 191-207. [CrossRef]

45. Lambert, J.M.; Morris, C.Q. Antibody-drug conjugates (adcs) for personalized treatment of solid tumors: A review. Adv. Ther. 2017, 34, 1015-1035. [CrossRef]

46. Levin, D.; Golding, B.; Strome, S.E.; Sauna, Z.E. Fc fusion as a platform technology: Potential for modulating immunogenicity. Trends Biotechnol. 2015, 33, 27-34. [CrossRef]

47. Henry, K.A. Next-generation DNA sequencing of vh/vl repertoires: A primer and guide to applications in single-domain antibody discovery. In Phage Display: Methods and Protocols; Hust, M., Lim, T.S., Eds.; Springer: New York, NY, USA, 2018; pp. 425-446.

48. Frenzel, A.; Roskos, L.; Klakamp, S.; Liang, M.; Arends, R.; Green, L. Antibody affinity. In Handbook of Therapeutic Antibodies, 2nd ed.; Wiley Blackwell: Hoboken, NJ, USA, 2014; Volume 1-4, pp. 115-140.

49. Hu, J.; Han, J.; Li, H.; Zhang, X.; Liu, L.; Chen, F.; Zeng, B. Human embryonic kidney 293 cells: A vehicle for biopharmaceutical manufacturing, structural biology, and electrophysiology. Cells Tissues Organs 2018, 205, 1-8. [CrossRef]

50. Jacobi, A.; Enenkel, B.; Garidel, P.; Eckermann, C.; Knappenberger, M.; Presser, I.; Kaufmann, H. Process development and manufacturing of therapeutic antibodies. In Handbook of Therapeutic Antibodies, 2nd ed.; Wiley Blackwell: Hoboken, NJ, USA, 2014; Volume 2-4, pp. 601-664.

51. Kayser, V.; Chennamsetty, N.; Voynov, V.; Helk, B.; Forrer, K.; Trout, B.L. A screening tool for therapeutic monoclonal antibodies: Identifying the most stable protein and its best formulation based on thioflavin $\mathrm{t}$ binding. Biotechnol. J. 2012, 7, 127-132. [CrossRef]

52. Tada, M.; Tatematsu, K.-I.; Ishii-Watabe, A.; Harazono, A.; Takakura, D.; Hashii, N.; Sezutsu, H.; Kawasaki, N. Characterization of anti-cd20 monoclonal antibody produced by transgenic silkworms (bombyx mori). $m A b s$ 2015, 7, 1138-1150. [CrossRef]

53. Maccani, A.; Landes, N.; Stadlmayr, G.; Maresch, D.; Leitner, C.; Maurer, M.; Gasser, B.; Ernst, W.; Kunert, R.; Mattanovich, D. Pichia pastoris secretes recombinant proteins less efficiently than chinese hamster ovary cells but allows higher space-time yields for less complex proteins. Biotechnol. J. 2014, 9, 526-537. [CrossRef]

54. Frenzel, A.; Hust, M.; Schirrmann, T. Expression of recombinant antibodies. Front. Immunol. 2013, 4, 217. [CrossRef]

55. Thoring, L.; Kubick, S. Versatile cell-free protein synthesis systems based on chinese hamster ovary cells. In Recombinant Protein Expression in Mammalian Cells: Methods and Protocols; Hacker, D.L., Ed.; Springer: New York, NY, USA, 2018; pp. 289-308. 
56. Tran, K.; Gurramkonda, C.; Cooper, M.A.; Pilli, M.; Taris, J.E.; Selock, N.; Han, T.-C.; Tolosa, M.; Zuber, A.; Peñalber-Johnstone, C.; et al. Cell-free production of a therapeutic protein: Expression, purification, and characterization of recombinant streptokinase using a cho lysate. Biotechnol. Bioeng. 2018, 115, 92-102. [CrossRef]

57. Stech, M.; Nikolaeva, O.; Thoring, L.; Stöcklein, W.F.M.; Wüstenhagen, D.A.; Hust, M.; Dübel, S.; Kubick, S. Cell-free synthesis of functional antibodies using a coupled in vitro transcription-translation system based on cho cell lysates. Sci. Rep. 2017, 7, 12030. [CrossRef]

58. Li, J.; Wang, H.; Kwon, Y.-C.; Jewett, M.C. Establishing a high yielding streptomyces-based cell-free protein synthesis system. Biotechnol. Bioeng. 2017, 114, 1343-1353. [CrossRef]

59. Jaroentomeechai, T.; Stark, J.C.; Natarajan, A.; Glasscock, C.J.; Yates, L.E.; Hsu, K.J.; Mrksich, M.; Jewett, M.C.; DeLisa, M.P. Single-pot glycoprotein biosynthesis using a cell-free transcription-translation system enriched with glycosylation machinery. Nat. Commun. 2018, 9, 2686. [CrossRef]

60. Gurramkonda, C.; Rao, A.; Borhani, S.; Pilli, M.; Deldari, S.; Ge, X.; Pezeshk, N.; Han, T.-C.; Tolosa, M.; Kostov, Y.; et al. Improving the recombinant human erythropoietin glycosylation using microsome supplementation in cho cell-free system. Biotechnol. Bioeng. 2018, 115, 1253-1264. [CrossRef]

61. Nakamura, T.; Omasa, T. Optimization of cell line development in the gs-cho expression system using a high-throughput, single cell-based clone selection system. J. Biosci. Bioeng. 2015, 120, 323-329. [CrossRef]

62. Zhou, Y.; Raju, R.; Alves, C.; Gilbert, A. Debottlenecking protein secretion and reducing protein aggregation in the cellular host. Curr. Opin. Biotechnol. 2018, 53, 151-157. [CrossRef]

63. Inwood, S.; Betenbaugh, M.J.; Lal, M.; Shiloach, J. Genome-wide high-throughput rnai screening for identification of genes involved in protein production. In Recombinant Protein Expression in Mammalian Cells: Methods and Protocols; Hacker, D.L., Ed.; Springer: New York, NY, USA, 2018; pp. 209-219.

64. Dangi, A.K.; Sinha, R.; Dwivedi, S.; Gupta, S.K.; Shukla, P. Cell line techniques and gene editing tools for antibody production: A review. Front. Pharmacol. 2018, 9, 630. [CrossRef]

65. Delic, M.; Göngrich, R.; Mattanovich, D.; Gasser, B. Engineering of protein folding and secretion-Strategies to overcome bottlenecks for efficient production of recombinant proteins. Antioxid. Redox Signal. 2014, 21, 414-437. [CrossRef]

66. Zhong, X.; Wright, J.F. Biological insights into therapeutic protein modifications throughout trafficking and their biopharmaceutical applications. Int. J. Cell Biol. 2013, 2013, 19. [CrossRef]

67. Altamirano, C.; Berrios, J.; Vergara, M.; Becerra, S. Advances in improving mammalian cells metabolism for recombinant protein production. Electron. J. Biotechnol. 2013, 16. [CrossRef]

68. Parola, C.; Mason, D.M.; Zingg, A.; Neumeier, D.; Reddy, S.T. Genome engineering of hybridomas to generate stable cell lines for antibody expression. In Recombinant Protein Expression in Mammalian Cells: Methods and Protocols; Hacker, D.L., Ed.; Springer: New York, NY, USA, 2018; pp. 79-111.

69. You, M.; Yang, Y.; Zhong, C.; Chen, F.; Wang, X.; Jia, T.; Chen, Y.; Zhou, B.; Mi, Q.; Zhao, Q.; et al. Efficient mab production in cho cells with optimized signal peptide, codon, and utr. Appl. Microbiol. Biotechnol. 2018, 102, 5953-5964. [CrossRef]

70. Mauro, V.P.; Chappell, S.A. Considerations in the use of codon optimization for recombinant protein expression. In Recombinant Protein Expression in Mammalian Cells: Methods and Protocols; Hacker, D.L., Ed.; Springer: New York, NY, USA, 2018; pp. 275-288.

71. Michael, I.P.; Nagy, A. Inducible protein production in 293 cells using the piggybac transposon system. In Recombinant Protein Expression in Mammalian Cells: Methods and Protocols; Hacker, D.L., Ed.; Springer: New York, NY, USA, 2018; pp. 57-68.

72. Balasubramanian, S. Recombinant cho cell pool generation using piggybac transposon system. In Recombinant Protein Expression in Mammalian Cells: Methods and Protocols; Hacker, D.L., Ed.; Springer: New York, NY, USA, 2018; pp. 69-78.

73. Jäger, V.; Büssow, K.; Schirrmann, T. Transient recombinant protein expression in mammalian cells. In Animal Cell Culture; Al-Rubeai, M., Ed.; Springer International Publishing: Cham, Switzerland, 2015; pp. $27-64$.

74. Wijesuriya, S.D.; Pongo, E.; Tomic, M.; Zhang, F.; Garcia-Rodriquez, C.; Conrad, F.; Farr-Jones, S.; Marks, J.D.; Horwitz, A.H. Antibody engineering to improve manufacturability. Protein Expression Purif. 2018, 149, 75-83. [CrossRef] 
75. L'Abbé, D.; Bisson, L.; Gervais, C.; Grazzini, E.; Durocher, Y. Transient gene expression in suspension hek293-ebna1 cells. In Recombinant Protein Expression in Mammalian Cells: Methods and Protocols; Hacker, D.L., Ed.; Springer: New York, NY, USA, 2018; pp. 1-16.

76. Arena, T.A.; Harms, P.D.; Wong, A.W. High throughput transfection of hek293 cells for transient protein production. In Recombinant Protein Expression in Mammalian Cells: Methods and Protocols; Hacker, D.L., Ed.; Springer: New York, NY, USA, 2018; pp. 179-187.

77. Agrawal, V.; Yu, B.; Pagila, R.; Yang, B.; Simonsen, C.; Beske, O. A high-yielding, cho-k1-based transient transfection system. BioProcess Int. 2013, 11, 28-35.

78. Hacker, D.L.; Kiseljak, D.; Rajendra, Y.; Thurnheer, S.; Baldi, L.; Wurm, F.M. Polyethyleneimine-based transient gene expression processes for suspension-adapted hek-293e and cho-dg44 cells. Protein Expression Purif. 2013, 92, 67-76. [CrossRef]

79. Ritacco, F.V.; Wu, Y.; Khetan, A. Cell culture media for recombinant protein expression in chinese hamster ovary (cho) cells: History, key components, and optimization strategies. Biotechnol. Prog. 2018, 34, 1407-1426. [CrossRef]

80. Whitford, W.G.; Lundgren, M.; Fairbank, A. Chapter 8-Cell culture media in bioprocessing. In Biopharmaceutical Processing; Jagschies, G., Lindskog, E., Łacki, K., Galliher, P., Eds.; Elsevier: Amsterdam, The Netherlands, 2018; pp. 147-162.

81. Davami, F.; Eghbalpour, F.; Barkhordari, F.; Mahboudi, F. Effect of peptone feeding on transient gene expression process in cho dg44. Avicenna J. Med. Biotechnol. 2014, 6, 147-155.

82. Mahboudi, F.; Abolhassan, M.R.; Azarpanah, A.; Aghajani-Lazarjani, H.; Sadeghi-Haskoo, M.A.; Maleknia, S.; Vaziri, B. The role of different supplements in expression level of monoclonal antibody against human cd20. Avicenna J. Med. Biotechnol. 2013, 5, 140-147.

83. You, M.; Liu, Y.; Chen, Y.; Guo, J.; Wu, J.; Fu, Y.; Shen, R.; Qi, R.; Luo, W.; Xia, N. Maximizing antibody production in suspension-cultured mammalian cells by the customized transient gene expression method. Biosci. Biotechnol. Biochem. 2013, 77, 1207-1213. [CrossRef]

84. Backliwal, G.; Hildinger, M.; Kuettel, I.; Delegrange, F.; Hacker, D.L.; Wurm, F.M. Valproic acid: A viable alternative to sodium butyrate for enhancing protein expression in mammalian cell cultures. Biotechnol. Bioeng. 2008, 101, 182-189. [CrossRef]

85. Elgundi, Z.; Sifniotis, V.; Reslan, M.; Cruz, E.; Kayser, V. Laboratory scale production and purification of a therapeutic antibody. JoVE 2017. [CrossRef]

86. Kim, S.J.; Ha, G.S.; Lee, G.; Lim, S.I.; Lee, C.M.; Yang, Y.H.; Lee, J.; Kim, J.E.; Lee, J.H.; Shin, Y.; et al. Enhanced expression of soluble antibody fragments by low-temperature and overdosing with a nitrogen source. Enzyme Microb. Technol. 2018, 115, 9-15. [CrossRef]

87. Lalonde, M.-E.; Durocher, Y. Therapeutic glycoprotein production in mammalian cells. J. Biotechnol. 2017, 251, 128-140. [CrossRef]

88. Rajendra, Y.; Kiseljak, D.; Baldi, L.; Hacker, D.L.; Wurm, F.M. A simple high-yielding process for transient gene expression in cho cells. J. Biotechnol. 2011, 153, 22-26. [CrossRef]

89. Codamo, J.; Munro, T.P.; Hughes, B.S.; Song, M.; Gray, P.P. Enhanced cho cell-based transient gene expression with the epi-cho expression system. Mol. Biotechnol. 2011, 48, 109-115. [CrossRef]

90. Codamo, J.; Hou, J.J.C.; Hughes, B.S.; Gray, P.P.; Munro, T.P. Efficient mab production in cho cells incorporating pei-mediated transfection, mild hypothermia and the co-expression of xbp-1. J. Chem. Technol. Biotechnol. 2011, 86, 923-934. [CrossRef]

91. Castan, A.; Schulz, P.; Wenger, T.; Fischer, S. Chapter 7-Cell line development. In Biopharmaceutical Processing; Jagschies, G., Lindskog, E., Łącki, K., Galliher, P., Eds.; Elsevier: Amsterdam, The Netherlands, 2018; pp. 131-146.

92. Lindskog, E.K. Chapter 31-The upstream process: Principal modes of operation. In Biopharmaceutical Processing; Jagschies, G., Lindskog, E., Łącki, K., Galliher, P., Eds.; Elsevier: Amsterdam, The Netherlands, 2018; pp. 625-635.

93. Fisher, A.C.; Kamga, M.-H.; Agarabi, C.; Brorson, K.; Lee, S.L.; Yoon, S. The current scientific and regulatory landscape in advancing integrated continuous biopharmaceutical manufacturing. Trends Biotechnol. 2018, 37, 253-267. [CrossRef]

94. Rathore, A.S.; Agarwal, H.; Sharma, A.K.; Pathak, M.; Muthukumar, S. Continuous processing for production of biopharmaceuticals. Prep. Biochem. Biotechnol. 2015, 45, 836-849. [CrossRef] 
95. Shukla, A.A.; Suda, E. Chapter 3-Harvest and recovery of monoclonal antibodies: Cell removal and clarification. In Process Scale Purification of Antibodies; Gottschalk, U., Ed.; John Wiley \& Sons, Inc.: Hoboken, NJ, USA, 2017; pp. 55-79.

96. Thömmes, J.; Twyman, R.M.; Gottschalk, U. Chapter 10-Alternatives to packed-bed chromatography for antibody extraction and purification. In Process Scale Purification of Antibodies; Gottschalk, U., Ed.; John Wiley \& Sons: Hoboken, NJ, USA, 2017; pp. 215-231.

97. Glynn, J. Chapter 11-Process-scale precipitation of impurities in mammalian cell culture broth. In Process Scale Purification of Antibodies; Gottschalk, U., Ed.; John Wiley \& Sons, Inc.: Hoboken, NJ, USA, 2017; pp. 233-246.

98. Singh, N.; Arunkumar, A.; Chollangi, S.; Tan, Z.G.; Borys, M.; Li, Z.J. Clarification technologies for monoclonal antibody manufacturing processes: Current state and future perspectives. Biotechnol. Bioeng. 2016, 113, 698-716. [CrossRef]

99. Singh, N.; Chollangi, S. Chapter 4-Next-generation clarification technologies for the downstream processing of antibodies. In Process scale Purification of Antibodies; Gottschalk, U., Ed.; John Wiley \& Sons, Inc.: Hoboken, NJ, USA, 2017; pp. 81-112.

100. Kelley, B. Chapter 1-Downstream processing of monoclonal antibodies: Current practices and future opportunities. In Process Scale Purification of Antibodies; Gottschalk, U., Ed.; John Wiley \& Sons, Inc.: Hoboken, NJ, USA, 2017; pp. 1-21.

101. Danielsson, Å. Chapter 17-Affinity chromatography. In Biopharmaceutical Processing; Jagschies, G., Lindskog, E., Łącki, K., Galliher, P., Eds.; Elsevier: Amsterdam, The Netherlands, 2018; pp. 367-378.

102. Kinna, A.; Tolner, B.; Rota, E.M.; Titchener-Hooker, N.; Nesbeth, D.; Chester, K. Imac capture of recombinant protein from unclarified mammalian cell feed streams. Biotechnol. Bioeng. 2016, 113, 130-140. [CrossRef]

103. Ghose, S.; Jin, M.; Liu, J.; Hickey, J.; Lee, S. Chapter 14-Integrated polishing steps for monoclonal antibody purification. In Process Scale Purification of Antibodies; Gottschalk, U., Ed.; John Wiley \& Sons, Inc.: Hoboken, NJ, USA, 2017; pp. 303-323.

104. Joshi, V.; Shivach, T.; Kumar, V.; Yadav, N.; Rathore, A. Avoiding antibody aggregation during processing: Establishing hold times. Biotechnol. J. 2014, 9, 1195-1205. [CrossRef]

105. Liderfelt, J.; Royce, J. Chapter 23-Filtration methods for use in purification processes (concentration and buffer exchange). In Biopharmaceutical Processing; Jagschies, G., Lindskog, E., Łącki, K., Galliher, P., Eds.; Elsevier: Amsterdam, The Netherlands, 2018; pp. 441-453.

106. Anselmo, A.C.; Gokarn, Y.; Mitragotri, S. Non-invasive delivery strategies for biologics. Nat. Rev. Drug Discov. 2018, 18, 19. [CrossRef]

107. Sousa, D.; Ferreira, D.; Rodrigues, J.L.; Rodrigues, L.R. Chapter 14-Nanotechnology in targeted drug delivery and therapeutics. In Applications of Targeted Nano Drugs and Delivery Systems; Mohapatra, S.S., Ranjan, S., Dasgupta, N., Mishra, R.K., Thomas, S., Eds.; Elsevier: Amsterdam, The Netherlands, 2019; pp. 357-409.

108. Jani, R.; Krupa, G.; Rupal, J. Active targeting of nanoparticles: An innovative technology for drug delivery in cancer therapeutics. J. Drug Deliv. Ther. 2019. [CrossRef]

109. Abdelaziz, H.M.; Gaber, M.; Abd-Elwakil, M.M.; Mabrouk, M.T.; Elgohary, M.M.; Kamel, N.M.; Kabary, D.M.; Freag, M.S.; Samaha, M.W.; Mortada, S.M.; et al. Inhalable particulate drug delivery systems for lung cancer therapy: Nanoparticles, microparticles, nanocomposites and nanoaggregates. J. Control. Release 2018, 269, 374-392. [CrossRef]

110. Jackisch, C.; Kim, S.B.; Semiglazov, V.; Melichar, B.; Pivot, X.; Hillenbach, C.; Stroyakovskiy, D.; Lum, B.L.; Elliott, R.; Weber, H.A.; et al. Subcutaneous versus intravenous formulation of trastuzumab for her2-positive early breast cancer: Updated results from the phase iii hannah study. Ann. Oncol. 2015, 26, 320-325. [CrossRef]

111. Lambertini, M.; Pondé, N.F.; Solinas, C.; de Azambuja, E. Adjuvant trastuzumab: A 10-year overview of its benefit. Expert Rev. Anticancer Ther. 2017, 17, 61-74. [CrossRef]

112. Sanford, M. Subcutaneous trastuzumab: A review of its use in her2-positive breast cancer. Target. Oncol. 2014, 9, 85-94. [CrossRef]

113. Reichert, J.M. Adalimumab (humira ${ }^{\circledR}$ ). In Handbook of Therapeutic Antibodies, 2nd ed.; Wiley Blackwell: Hoboken, NJ, USA, 2014; Volume 3-4, pp. 1309-1322. 
114. Crommelin, D.J.A.; Hawe, A.; Jiskoot, W. Formulation of biologics including biopharmaceutical considerations. In Pharmaceutical Biotechnology: Fundamentals and Applications; Crommelin, D.J.A., Sindelar, R.D., Meibohm, B., Eds.; Springer International Publishing: Cham, Switzerland, 2019; pp. 83-103.

115. Singh, S.K.; Mahler, H.-C.; Hartman, C.; Stark, C.A. Are injection site reactions in monoclonal antibody therapies caused by polysorbate excipient degradants? J. Pharm. Sci. 2018, 107, 2735-2741. [CrossRef]

116. Rayaprolu, B.M.; Strawser, J.J.; Anyarambhatla, G. Excipients in parenteral formulations: Selection considerations and effective utilization with small molecules and biologics. Drug Dev. Ind. Pharm. 2018, 44, 1565-1571. [CrossRef]

117. Pimentel, F.F.; Morgan, G.; Tiezzi, D.G.; de Andrade, J.M. Development of new formulations of biologics: Expectations, immunogenicity, and safety for subcutaneous trastuzumab. Pharmaceut. Med. 2018, 32, 319-325. [CrossRef]

118. Garidel, P.; Kuhn, A.B.; Schäfer, L.V.; Karow-Zwick, A.R.; Blech, M. High-concentration protein formulations: How high is high? Eur. J. Pharm. Biopharm. 2017, 119, 353-360. [CrossRef]

119. Kemter, K.; Altrichter, J.; Derwand, R.; Kriehuber, T.; Reinauer, E.; Scholz, M. Amino acid-based advanced liquid formulation development for highly concentrated therapeutic antibodies balances physical and chemical stability and low viscosity. Biotechnol. J. 2018, 13, e1700523. [CrossRef]

120. Mandal, A.; Pal, D.; Agrahari, V.; Trinh, H.M.; Joseph, M.; Mitra, A.K. Ocular delivery of proteins and peptides: Challenges and novel formulation approaches. Adv. Drug Del. Rev. 2018, 126, 67-95. [CrossRef]

121. Reslan, M.; Kayser, V. The effect of deuterium oxide on the conformational stability and aggregation of bovine serum albumin. Pharm. Dev. Technol. 2016, 1-7. [CrossRef]

122. Reslan, M.; Ranganathan, V.; Macfarlane, D.R.; Kayser, V. Choline ionic liquid enhances the stability of herceptin(r) (trastuzumab). Chem. Commun. (Camb.) 2018, 54, 10622-10625. [CrossRef]

123. Reslan, M.; Kayser, V. Ionic liquids as biocompatible stabilizers of proteins. Biophys. Rev. 2018, 10, 781-793. [CrossRef]

124. Emami, F.; Vatanara, A.; Park, E.J.; Na, D.H. Drying technologies for the stability and bioavailability of biopharmaceuticals. Pharmaceutics 2018, 10, 131. [CrossRef]

125. Izutsu, K.I. Applications of freezing and freeze-drying in pharmaceutical formulations. In Adv. Exp. Med. Biol.; Springer: New York, NY, USA, 2018; Volume 1081, pp. 371-383.

126. Schermeyer, M.T.; Wöll, A.K.; Kokke, B.; Eppink, M.; Hubbuch, J. Characterization of highly concentrated antibody solution-A toolbox for the description of protein long-term solution stability. mAbs 2017, 9 , 1169-1185. [CrossRef]

127. Kayser, V.; Chennamsetty, N.; Voynov, V.; Helk, B.; Forrer, K.; Trout, B.L. Evaluation of a non-arrhenius model for therapeutic monoclonal antibody aggregation. J. Pharm. Sci. 2011, 100, 2526-2542. [CrossRef]

128. Rabia, L.A.; Desai, A.A.; Jhajj, H.S.; Tessier, P.M. Understanding and overcoming trade-offs between antibody affinity, specificity, stability and solubility. Biochem. Eng. J. 2018, 137, 365-374. [CrossRef]

129. Van de Bovenkamp, F.S.; Derksen, N.I.L.; van Breemen, M.J.; de Taeye, S.W.; Ooijevaar-de Heer, P.; Sanders, R.W.; Rispens, T. Variable domain n-linked glycans acquired during antigen-specific immune responses can contribute to immunoglobulin g antibody stability. Front. Immunol. 2018, 9, 740. [CrossRef]

130. Kuhn, A.B.; Kube, S.; Karow-Zwick, A.R.; Seeliger, D.; Garidel, P.; Blech, M.; Schäfer, L.V. Improved solution-state properties of monoclonal antibodies by targeted mutations. J. Phys. Chem. B 2017, 121, 10818-10827. [CrossRef]

131. Singh, S.N.; Yadav, S.; Shire, S.J.; Kalonia, D.S. Dipole-dipole interaction in antibody solutions: Correlation with viscosity behavior at high concentration. Pharm. Res. 2014, 31, 2549-2558. [CrossRef]

132. Ionescu, R.M.; Vlasak, J.; Price, C.; Kirchmeier, M. Contribution of variable domains to the stability of humanized igg1 monoclonal antibodies. J. Pharm. Sci. 2008, 97, 1414-1426. [CrossRef]

133. Liu, L. Pharmacokinetics of monoclonal antibodies and fc-fusion proteins. Protein Cell 2018, 9, 15-32. [CrossRef]

134. Schweizer, D.; Serno, T.; Goepferich, A. Controlled release of therapeutic antibody formats. Eur. J. Pharm. Biopharm. 2014, 88, 291-309. [CrossRef]

135. Rudnick, S.I.; Adams, G.P. Affinity and avidity in antibody-based tumor targeting. Cancer Biother. Radiopharm. 2009, 24, 155-161. [CrossRef]

136. Ickenstein, L.M.; Garidel, P. Hydrogel formulations for biologicals: Current spotlight from a commercial perspective. Ther. Deliv. 2018, 9, 221-230. [CrossRef] 
137. Saxena, A.; Wu, D. Advances in therapeutic fc engineering-Modulation of igg-associated effector functions and serum half-life. Front. Immunol. 2016, 7, 580. [CrossRef]

138. Jefferis, R. Glycosylation of antibody molecules. In Handbook of Therapeutic Antibodies, 2nd ed.; Wiley Blackwell: Hoboken, NJ, USA, 2014; Volume 1-4, pp. 171-200.

139. Zheng, K.; Bantog, C.; Bayer, R. The impact of glycosylation on monoclonal antibody conformation and stability. $m A$ bs 2011, 3, 568-576. [CrossRef]

140. Lei, C.; Gong, R.; Ying, T. Editorial: Antibody fc engineering: Towards better therapeutics. Front. Immunol. 2018, 9, 2450. [CrossRef]

141. Booth, B.J.; Ramakrishnan, B.; Narayan, K.; Wollacott, A.M.; Babcock, G.J.; Shriver, Z.; Viswanathan, K. Extending human igg half-life using structure-guided design. mAbs 2018, 10, 1098-1110. [CrossRef]

142. Kellner, C.; Otte, A.; Cappuzzello, E.; Klausz, K.; Peipp, M. Modulating cytotoxic effector functions by fc engineering to improve cancer therapy. Transfus. Med. Hemoth. 2017, 44, 327-336. [CrossRef]

143. Wang, Q.; Chen, Y.; Pelletier, M.; Cvitkovic, R.; Bonnell, J.; Chang, C.Y.; Koksal, A.C.; O'Connor, E.; Gao, X.; $\mathrm{Yu}$, X.Q.; et al. Enhancement of antibody functions through fc multiplications. mAbs 2017, 9, $393-403$. [CrossRef]

144. Lefranc, M.P.; Ehrenmann, F.; Kossida, S.; Giudicelli, V.; Duroux, P. Use of imgt ${ }^{\circledR}$ databases and tools for antibody engineering and humanization. In Methods Mol. Biol.; Humana Press Inc.: New York, NY, USA, 2018; Volume 1827, pp. 35-69.

145. Lefranc, M.-P.; Giudicelli, V.; Duroux, P.; Jabado-Michaloud, J.; Folch, G.; Aouinti, S.; Carillon, E.; Duvergey, H.; Houles, A.; Paysan-Lafosse, T.; et al. Imgt $\left({ }^{\circledR}\right)$, the international immunogenetics information system $\left({ }^{\circledR}\right)$ 25 years on. Nucleic Acids Res. 2015, 43, D413-D422. [CrossRef]

146. Martin, A.C.R.; Allen, J. Bioinformatics tools for analysis of antibodies. In Handbook of Therapeutic Antibodies, 2nd ed.; Wiley Blackwell: Hoboken, NJ, USA, 2014; Volume 1-4, pp. 201-228.

147. Śledź, P.; Caflisch, A. Protein structure-based drug design: From docking to molecular dynamics. Curr. Opin. Struct. Biol. 2018, 48, 93-102. [CrossRef]

148. Pandya, A.; Howard, M.J.; Zloh, M.; Dalby, P.A. An evaluation of the potential of nmr spectroscopy and computational modelling methods to inform biopharmaceutical formulations. Pharmaceutics 2018, 10, 1-24. [CrossRef]

149. Rathore, D.; Faustino, A.; Schiel, J.; Pang, E.; Boyne, M.; Rogstad, S. The role of mass spectrometry in the characterization of biologic protein products. Expert Rev. Proteomic. 2018, 15, 431-449. [CrossRef]

150. Wang, X.; An, Z.; Luo, W.; Xia, N.; Zhao, Q. Molecular and functional analysis of monoclonal antibodies in support of biologics development. Protein Cell 2018, 9, 74-85. [CrossRef]

151. Baker Edward, N. Crystallography and the development of therapeutic medicines. IUCrJ 2018, 5, 118-119. [CrossRef]

152. Vénien-Bryan, C.; Li, Z.; Vuillard, L.; Boutin, J.A. Cryo-electron microscopy and X-ray crystallography: Complementary approaches to structural biology and drug discovery. Acta Crystallogr. Sect. F Struct. Biol. Commun. 2017, 73, 174-183. [CrossRef]

153. Brader, M.L.; Baker, E.N.; Dunn, M.F.; Laue, T.M.; Carpenter, J.F. Using x-ray crystallography to simplify and accelerate biologics drug development. J. Pharm. Sci. 2017, 106, 477-494. [CrossRef]

154. Nero, T.L.; Parker, M.W.; Morton, C.J. Protein structure and computational drug discovery. Biochem. Soc. Trans. 2018, 46, 1367-1379. [CrossRef]

155. Blaffert, J.; Haeri, H.H.; Blech, M.; Hinderberger, D.; Garidel, P. Spectroscopic methods for assessing the molecular origins of macroscopic solution properties of highly concentrated liquid protein solutions. Anal. Biochem. 2018, 561-562, 70-88. [CrossRef]

156. Brinson, R.G.; Marino, J.P.; Delaglio, F.; Arbogast, L.W.; Evans, R.M.; Kearsley, A.; Gingras, G.; Ghasriani, H.; Aubin, Y.; Pierens, G.K.; et al. Enabling adoption of 2d-nmr for the higher order structure assessment of monoclonal antibody therapeutics. $m A b s$ 2019, 11, 94-105. [CrossRef]

157. Young, J.A.; Gabrielson, J.P. Higher order structure methods for similarity assessment. In Biosimilars: Regulatory, Clinical, and Biopharmaceutical Development; Gutka, H.J., Yang, H., Kakar, S., Eds.; Springer International Publishing: Cham, Switzerland, 2018; pp. 321-337.

158. Kumar, S.; Plotnikov, N.V.; Rouse, J.C.; Singh, S.K. Biopharmaceutical informatics: Supporting biologic drug development via molecular modelling and informatics. J. Pharm. Pharmacol. 2018, 70, 595-608. [CrossRef] 
159. Westbrook, J.D.; Burley, S.K. How structural biologists and the protein data bank contributed to recent fda new drug approvals. Structure 2018, 27, 211-217. [CrossRef]

160. Burley, S.K.; Berman, H.M.; Christie, C.; Duarte, J.M.; Feng, Z.; Westbrook, J.; Young, J.; Zardecki, C. Rcsb protein data bank: Sustaining a living digital data resource that enables breakthroughs in scientific research and biomedical education. Protein Sci. 2018, 27, 316-330. [CrossRef]

161. Kuroda, D.; Tsumoto, K. Antibody affinity maturation by computational design. In Methods Mol. Biol.; Humana Press Inc.: New York, NY, USA, 2018; Volume 1827, pp. 15-34.

162. Fischman, S.; Ofran, Y. Computational design of antibodies. Curr. Opin. Struct. Biol. 2018, 51, $156-162$. [CrossRef]

163. Adolf-Bryfogle, J.; Kalyuzhniy, O.; Kubitz, M.; Weitzner, B.D.; Hu, X.; Adachi, Y.; Schief, W.R.; Dunbrack, R.L., Jr. Rosettaantibodydesign (rabd): A general framework for computational antibody design. PLoS Comp. Biol. 2018, 14, e1006112. [CrossRef]

164. Branco, R.J.; Dias, A.M.; Roque, A.C. Understanding the molecular recognition between antibody fragments and protein a biomimetic ligand. J. Chromatogr. A 2012, 1244, 106-115. [CrossRef]

165. Huang, B.; Liu, F.F.; Dong, X.Y.; Sun, Y. Molecular mechanism of the affinity interactions between protein a and human immunoglobulin g1 revealed by molecular simulations. J. Phys. Chem. B 2011, 115, 4168-4176. [CrossRef]

166. Van der Kant, R.; van Durme, J.; Rousseau, F.; Schymkowitz, J. Solubis: Optimizing protein solubility by minimal point mutations. In Methods Mol. Biol.; Humana Press Inc.: New York, NY, USA, 2019; Volume 1873, pp. 317-333.

167. Gil-Garcia, M.; Banó-Polo, M.; Varejao, N.; Jamroz, M.; Kuriata, A.; Díaz-Caballero, M.; Lascorz, J.; Morel, B.; Navarro, S.; Reverter, D.; et al. Combining structural aggregation propensity and stability predictions to redesign protein solubility. Mol. Pharm. 2018, 15, 3846-3859. [CrossRef]

168. Seeliger, D.; Schulz, P.; Litzenburger, T.; Spitz, J.; Hoerer, S.; Blech, M.; Enenkel, B.; Studts, J.M.; Garidel, P.; Karow, A.R. Boosting antibody developability through rational sequence optimization. $m A$ bs 2015, 7, 505-515. [CrossRef]

169. Chennamsetty, N.; Voynov, V.; Kayser, V.; Helk, B.; Trout, B.L. Prediction of aggregation prone regions of therapeutic proteins. J. Phys. Chem. B 2010, 114, 6614-6624. [CrossRef]

170. Chennamsetty, N.; Voynov, V.; Kayser, V.; Helk, B.; Trout, B.L. Design of therapeutic proteins with enhanced stability. Proc. Natl. Acad. Sci. USA 2009, 106, 11937-11942. [CrossRef]

171. Majumder, S.; Jones, M.T.; Kimmel, M.; Alphonse Ignatius, A. Probing conformational diversity of fc domains in aggregation-prone monoclonal antibodies. Pharm. Res. 2018, 35, 220. [CrossRef]

172. Nakamura, H.; Oda-Ueda, N.; Ueda, T.; Ohkuri, T. Introduction of a glycosylation site in the constant region decreases the aggregation of adalimumab fab. Biochem. Biophys. Res. Commun. 2018, 503, 752-756. [CrossRef]

173. Pepinsky, R.B.; Silvian, L.; Berkowitz, S.A.; Farrington, G.; Lugovskoy, A.; Walus, L.; Eldredge, J.; Capili, A.; Mi, S.; Graff, C.; et al. Improving the solubility of anti-lingo-1 monoclonal antibody li33 by isotype switching and targeted mutagenesis. Protein Sci. 2010, 19, 954-966. [CrossRef]

174. Wu, S.-J.; Luo, J.; O’Neil, K.T.; Kang, J.; Lacy, E.R.; Canziani, G.; Baker, A.; Huang, M.; Tang, Q.M.; Raju, T.S.; et al. Structure-based engineering of a monoclonal antibody for improved solubility. Protein Eng. Des. Sel. 2010, 23, 643-651. [CrossRef]

(C) 2019 by the authors. Licensee MDPI, Basel, Switzerland. This article is an open access article distributed under the terms and conditions of the Creative Commons Attribution (CC BY) license (http://creativecommons.org/licenses/by/4.0/). 